\title{
GRENVILLE SKARN TITANITE: POTENTIAL REFERENCE MATERIAL FOR SIMS U-Th-Pb ANALYSIS
}

\author{
ALLEN K. KENNEDY $\$$ \\ Department of Imaging and Applied Physics, Curtin University, Kent Street, Bentley, 6102, WA, Australia
}

SANDRA L. KAMO

Jack Satterly Geochronology Laboratory, Department of Geology, University of Toronto, 22 Russell St., Toronto, Ontario M5S 3B1, Canada

LUTZ NASDALA

Institut für Mineralogie und Kristallographie, Universität Wien, Althanstr. 14, A-1090 Wien, Austria

\author{
NICOLAS E. TIMMS
}

The Institute for Geoscience Research, Department of Applied Geology, Curtin University of Technology, Kent Street, Bentley, 6102, WA, Australia

\begin{abstract}
We have investigated the homogeneity, chemical composition, structure, degree of radiation damage, and post-formation evolution of titanite crystals from skarns of the Grenville Province of the Canadian Shield using SHRIMP, TIMS, Raman and PL spectroscopy, EBSD, and EPMA-WDS. These results are used to assess the potential of the titanite as Reference Material (RM) for micro-analytical U-Th-Pb age dating. The SHRIMP data show that these megacrysts (5-31g) have concordant U-Pb isotope systematics, 60 to $500 \mathrm{ppm} \mathrm{U}, 120$ to $1200 \mathrm{ppm} \mathrm{Th},{ }^{206} \mathrm{~Pb} /{ }^{204} \mathrm{~Pb}$ between 500 and 2500 , ages of $\sim 1 \mathrm{Ga}$, and excellent homogeneity at the scale of the analytical volume of the ion probe. The ID-TIMS titanite data for OLT1, OLT2 and TCB show that these crystals are essentially concordant. Data for OLT1 and OLT2 show slight scatter (i.e., in excess of that expected from the uncertainty in an individual analysis). For OLT1, one of seven analyses shows Pb loss or, possibly, a younger period of growth. Crystals OLT1 and OLT2 have respective TIMS concordia ages of $1014.8 \pm 2.0 \mathrm{Ma}(2 \sigma, n=6, \mathrm{MSWD}=1.8)$ and $998.0 \pm 4.5 \mathrm{Ma}(2 \sigma, n=3, \mathrm{MSWD}=3.3)$ for domains that have not lost $\mathrm{Pb}$. The TIMS analyses of TCB are tightly clustered and give a concordia age of $1018.1 \pm 1.7 \mathrm{Ma}(2 \sigma, n=4$, MSWD $=0.92)$. Raman and PL spectra show a low to moderate degree of accumulated radiation-induced damage in the Grenville Skarn Titanite crystals and uniform internal distributions of this damage. The EDSB contrast images indicate little or no crystallographic misorientation. The EMPA-WDS data show that the outer 50-100 $\mu \mathrm{m}$ of the OLT1 and TCB crystals are enriched in Al and F, and depleted in Fe and $\mathrm{Nb}$, when compared with the interior. In spite of the variation in composition and degree of radiation damage amongst samples, there are no identifiable matrix effects in our SHRIMP data. Some Grenville skarn titanite (GST) crystals have potential as RM for micro-analytical U-Th-Pb age dating. Crystal TCB has excellent homogeneity of U-Th-Pb isotopic composition. Crystals OLT1 and OLT2 have minor TIMS age heterogeneity. However, this heterogeneity is smaller than that of the Khan titanite, our current in-house titanite standard. Careful selection of analysis areas during SIMS, and of chips for TIMS analysis, allows high-quality isotopic data to be obtained from these large crystals of titanite.
\end{abstract}

Keywords: titanite, reference material, Grenville Province, skarn, SHRIMP, TIMS, Raman, EBSD, geochronology.

\section{SOMMAIRE}

Nous avons caractérisé l'homogénéité, la composition chimique, la structure, le degré de dommage dû à la radiation, et l'évolution post-formation de mégacristaux de titanite prélevés de skarns dans la Province de Grenville du Bouclier Canadien au moyen d'analyses SHRIMP, TIMS, spectroscopie Raman et Photoluminescence (PL), EBSD, et EPMA-WDS. Ces résultats

$\S \quad$ E-mail address: a.kennedy@exchange.curtin.au.edu 
servent à évaluer leur potentiel comme matériaux de référence pour datations U-Th-Pb micro-analytiques. Les données SHRIMP montrent que ces mégacristaux $(5-31 \mathrm{~g})$ possèdent des relations concordantes dans le système isotopique U-Pb, de 60 à 500 ppm U, de 120 à $1200 \mathrm{ppm} \mathrm{Th}$, une valeur de ${ }^{206} \mathrm{~Pb} /{ }^{204} \mathrm{~Pb}$ entre 500 et 2500 , un âge d'environ $1 \mathrm{Ga}$, et un degré d'homogénéité excellent à l'échelle du volume analysé avec la sonde ionique. Les données ID-TIMS portant sur les cristaux de titanite OLT1, OLT2 et TCB montrent qu'ils sont essentiellement concordants. Les données décrivant OLT1 et OLT2 montrent une légère dispersion, en excès de ce que l'on pourrait anticiper d'une analyse individuelle. Dans le cas de OLT1, une des sept analyses révèle une perte de $\mathrm{Pb}$ ou, peut-être, une période de croissance plus jeune. Les cristaux OLT1 et OLT2 démontrent des âges concordia TIMS de $1014.8 \pm 2.0 \mathrm{Ma}(2 \sigma, n=6, \mathrm{MSWD}=1.8)$ et $998.0 \pm 4.5 \mathrm{Ma}(2 \sigma, n=3, \mathrm{MSWD}=3.3)$, respectivement, pour les domaines qui n'ont pas perdu de $\mathrm{Pb}$. Les résultats TIMS pour le cristal TCB définissent une fourchete serrée et donnent un âge concordia de $1018.1 \pm 1.7 \mathrm{Ma}(2 \sigma, n=4, \mathrm{MSWD}=0.92)$. Les spectres Raman et PL montrent un degré de dommage accumulé suite à la radiation variant de faible à modéré, et une distribution interne uniforme du dommage. Les images obtenues par contraste EDSB indiquent très peu de désorientation cristallographique, ou bien aucune. Les compositions acquise avec une microsonde électronique en dispersion de longueurs d'ondes montrent qu'un liseré externe de 50-100 $\mu \mathrm{m}$ des cristaux OLT1 et $\mathrm{TCB}$ est enrichi en $\mathrm{Al}$ et $\mathrm{F}$, et appauvri en Fe et $\mathrm{Nb}$, par rapport à l'intérieur. Malgré les variations en composition et en degré de dommage dû à la radiation, nous ne voyons aucun effect de matrice dans nos données SHRIMP. Certains cristaux de titanite des skarns de Grenville ont donc un bon potentiel pour servir de matériaux de référence pour déterminations micro-analytiques de l'âge U-Th-Pb. Le cristal TCB possède une excellente homogénéité des isotopes U-Th-Pb. Les cristaux OLT1 et OLT2 font preuve d'une légère hétérogénéité dans les âges TIMS. Toutefois, cette hétérogénéité est inférieure à celle de la titanite de Khan, notre étalon interne présentement. Une sélection soignée des domaines à analyser au cours des sessions SIMS, et des fragments pour un analyse par TIMS, nous permettra d'obtenir des données isotopiques de qualité supérieure de ces mégacristaux de titanite.

(Traduit par la Rédaction)

Mots-clés: titanite, matériaux de référence, Province de Grenville, skarn, SHRIMP, TIMS, Raman, EBSD, géochronologie.

\section{INTRODUCTION}

Titanite $\left(\mathrm{CaTiSiO}_{5}\right)$, a ubiquitous major-element phase in calcic igneous and metamorphic rocks, may in some cases incorporate 10 s to 100 s of ppm of $U$ and Th. The high contents of $U$ and $\mathrm{Th}$, along with a high closure-temperature for $\mathrm{Pb}$ diffusion $\left(700-750^{\circ} \mathrm{C}\right.$ : Cherniak 1993, Parrish \& Whitehouse 1999), make titanite an important accessory mineral in $\mathrm{U}-\mathrm{Th}-\mathrm{Pb}$ Thermal Ionization Mass Spectrometry (TIMS), Secondary Ion Mass Spectrometry (SIMS) and Laser Ablation - Inductively Coupled Plasma - Mass Spectrometry (LA-ICPMS) geochronology (e.g., Corfu 1996, Frei et al. 1997, Corfu \& Stone 1998, Ketchum et al. 1998, Frost et al. 2001, Aleinikoff 2002, Storkey et al. 2005, Bakker \& Elburg 2006, Storey et al. 2006, Frost \& Fanning 2006, Buick et al. 2007, Amelin 2009, Heaman 2009, Smith et al. 2009). The accuracy and precision of SIMS and LA-ICP-MS U-Th-Pb methods depend on the quality of the reference materials (RM); currently, there is a limited choice of RM. Titanite from the Khan pegmatite (Kinny 1997, Heaman 2009) and BRL-1, a $1047 \mathrm{Ma}$ titanite from the Bear Lake Diggings, Ontario, Canada, (Aleinikoff et al. 2002, 2007, Frost \& Fanning 2006, Mazdab et al. 2009) are the only titanite samples that are widely distributed.

A reference material needs to be large enough, or abundant enough, that there is sufficient material for widespread distribution and reasonable longevity of use. We have focused our attention on identifying potential RM titanite from the U- and Th-rich skarns of the Grenville Province of the Canadian Shield, as it is likely that these occurrences of $\sim 1 \mathrm{Ga}$ titanite have sufficient $\mathrm{U}$ and $\mathrm{Th}$, and relatively low common $\mathrm{Pb}$ (Frei et al. 1997, Ketchum et al. 1998, Aleinikoff et al. 2002, 2007), and the crystals are large enough to allow for widespread distribution.

There are many difficulties in identifying and assessing titanite RM for micro-analysis. Still, titanite is widespread in calcic igneous rocks, it provides invaluable $\mathrm{P}-\mathrm{T}$ information in calcareous metamorphic systems (Hayden et al. 2008), and its use in geochronology is rapidly expanding. Additional titanite RM is needed for micro-analysis, and this has provided incentive for us to characterize a group of crystals of Grenville Skarn Titanite (GST).

\section{BACKGROUND INFORMATION}

There are a number of reasons for the lack of titanite RMs. Finding natural titanite with a homogeneous bulkcomposition is very difficult. Complex schemes of solid solution, with variations of $\mathrm{Ca}, \mathrm{Ti}, \mathrm{Fe}, \mathrm{Al}$, and $\mathrm{F}$ at the percentage level, are common in titanite (Spear 1981, Bernau \& Franz 1987, Xirouchakis \& Lindsley 1998, Markl \& Piazolo 1999, Frost et al. 2001, Hayden et al. 2008). The chemical composition of titanite can be affected by growth kinetics, and many titanite crystals exhibit complex or sector zoning (Paterson \& Stephens 1992). This heterogeneity is a major disadvantage for micro-analytical techniques if there are matrix effects that produce spurious ages (Fletcher et al. 2010).

The partition coefficients for $U$ and $T h$ in titanite are lower than those of many other accessory minerals used for geochronology, such as zircon, monazite, and xenotime, and common $\mathrm{Pb}$ substitutes readily for $\mathrm{Ca}$ in 
titanite. In addition, the modal abundance of titanite is commonly at the percentage level; this means that the radiogenic parent elements are present at low levels because of dilution throughout the large volume of titanite (Frost et al. 2001). Thus, it can be difficult to find a titanite crystal with sufficient $U$ and Th to give good analytical precision for micro-analysis techniques. In addition, low initial $\mathrm{Pb}$ is required so that the correction for common $\mathrm{Pb}$ has a minor effect on analytical precision. Also, in some cases, natural titanite is unsuitable as reference materials owing to metamictization. Radiation damage and subsequent alteration have the potential to produce discordant analyses owing to recent or ancient $\mathrm{Pb}$ loss, or to radiation-damage-induced matrix effects changing the sputtering characteristics of $\mathrm{U}$ and $\mathrm{Pb}$.

Synthetic titanite and glasses of titanite composition are being produced by experimental techniques (Prowatke \& Klemme 2006, Ødegård et al. 2007, Mazdab et al. 2009), but these are not currently used as a U-Th- $\mathrm{Pb}$ isotope RM. Whether they can be used as micro-analytical RM is unknown. Lead was included in the starting compositions of some experiments ( $\mathrm{F}$. Mazdab, pers. commun.), but the homogeneity of the $\mathrm{Pb}$ isotopic composition of the experimental run products has not been determined.

An ideal RM for micro-analysis must be isotopically homogeneous; this characteristic must be examined carefully when assessing large crystals of natural titanite, as inheritance of older components can occur in both igneous and metamorphic titanite (Corfu 1996, Pidgeon et al. 1996, Zhang \& Schärer 1996, Ketchum et al. 1998, Storey et al. 2006). Heaman (2009) has shown that the Khan titanite RM is isotopically heterogeneous in $\mathrm{U}-\mathrm{Pb}$ at the TIMS analytical volume. Multi-grain separates are unlikely to be useful as RM, as different age-populations of titanite can be present in a single rock (Getty \& Gromet 1992, Corfu 1996, Kamo et al. 1996, Verts et al. 1996, Corfu \& Stone 1998, Aleinikoff et al. 2002, 2007). Using Proterozoic or Archean titanite as a RM has the advantage that ${ }^{206} \mathrm{~Pb} /{ }^{204} \mathrm{~Pb}$, ${ }^{207} \mathrm{~Pb} /{ }^{206} \mathrm{~Pb}$ and ${ }^{208} \mathrm{~Pb} /{ }^{204} \mathrm{~Pb}$ are higher for any given $\mathrm{U}$ and Th content than younger titanite. However, there is a trade-off in that radiation damage increases with age. Detailed isotopic assessment of any potential titanite $\mathrm{RM}$ is essential.

\section{THE SAMPLES}

The materials studied are all single crystals from different coarse-grained skarns. Reference materials OLT1 and OLT2 are from the Ca-Ti-rich skarns at Otter Lake, Quebec, and have respective weights of 31 and $4.6 \mathrm{~g}$. Reference material TCB is a $5.5 \mathrm{~g}$ crystal from the Campbell's Bay area, Quebec. Figure 1A is a photograph of the OLT1 megacryst.
The Otter Lake area is located approximately $100 \mathrm{~km} \mathrm{NW}$ of Ottawa. These rocks are within the Grenville Province, which is the remains of a deeply eroded collisional mountain belt that formed between 1.3 and $1.0 \mathrm{Ga}$. The sample area forms part of the boundary between the Central Metasedimentary Belt and the Central Gneiss Belt, and mainly includes gneisses, marbles, amphibolites and skarns, which underwent upper-amphibolite-facies metamorphism at temperatures and pressures of 650 to $700^{\circ} \mathrm{C}$ and $6.5-7$ kbar during the Elzevirian and Ottawan phases of the Grenville orogeny (Kretz 1993, Kretz et al. 1999). Hydrothermal activity that accompanied metamorphism transformed portions of the Grenvillian marbles into pink or salmon-colored metasomatic units (Kretz 1990, 2009), and these form many of the skarns. In the Bancroft domain south of Otter Lake, Mezger et al. (1991) have shown that metamorphism during the Ottawan orogeny peaked at $c a$. 1045-1030 Ma, and that the Bancroft shear zone remained active from 1045 to 893 Ma. Ketchum et al. (1998) obtained titanite U-Pb ages ranging from 1049 to $956 \mathrm{Ma}$ for a small $(20 \times$ $20 \mathrm{~km}$ ) area of the southwestern Grenville Province, and have shown that micro-texture, strain state, structural position, titanite morphology, and host-rock $\mathrm{U}-\mathrm{Pb}$ data are essential for the interpretation of titanite ages. They concluded that titanite recorded (1) regional metamorphism (1049-1045 Ma), (2) closure-temperature ages during unroofing (1028-1018 Ma), (3) localized high-strain recrystallization and resetting (1008-1000 $\mathrm{Ma})$, and (4) late, fluid-phase-driven post-kinematic recrystallization (967-956 Ma).

Both OLT1, a $5 \times 5 \times 2 \mathrm{~cm}$ dark reddish brown single crystal, and OLT2, a $2 \times 1 \times 0.5 \mathrm{~cm}$ dark reddish brown single crystal, are from a large metasomatic calcite skarn at the Yates uranium prospect, in rocks that are rich in augite, scapolite, and titanite (Shaw 1958, Shaw et al. 1963a, 1963b, Trzcienski et al. 1974). The Yates locality also contains a second calcite skarn, with significantly different mineralogy, that contains abundant purple fluorite, and green fluorapatite, plus minor scapolite and diopside. Given the complexity of the Yates locality, and the presence of multiple skarns, we cannot be certain that our titanite samples are from the same skarn as the titanite studied by Frei et al. (1997). It is probable that the apatite sample studied by Barfod et al. (2005) is from a different skarn than our titanite.

The TCB titanite was purchased from a mineral dealer, and the locality was given as Campbell's Bay, Quebec, a small town located between Litchfield and Grand Calumet. Both Litchfield and Grand Calumet areas have numerous coarse-grained U-rich skarns and lenses that contain titanite (Shaw 1958), so the exact locality of TCB cannot be determined accurately from the information available. 
A

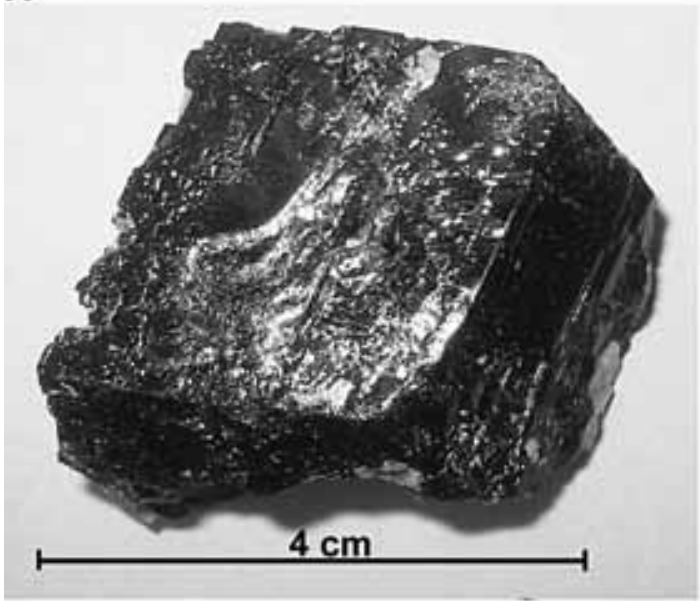

C

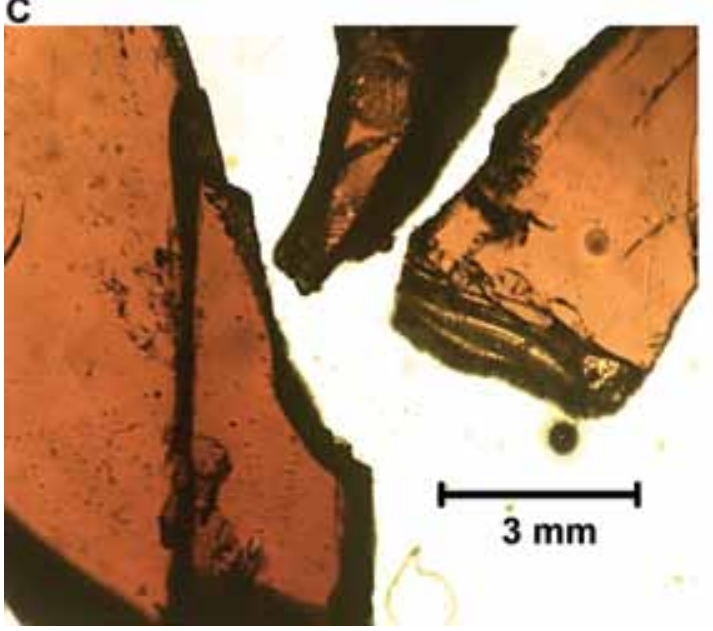

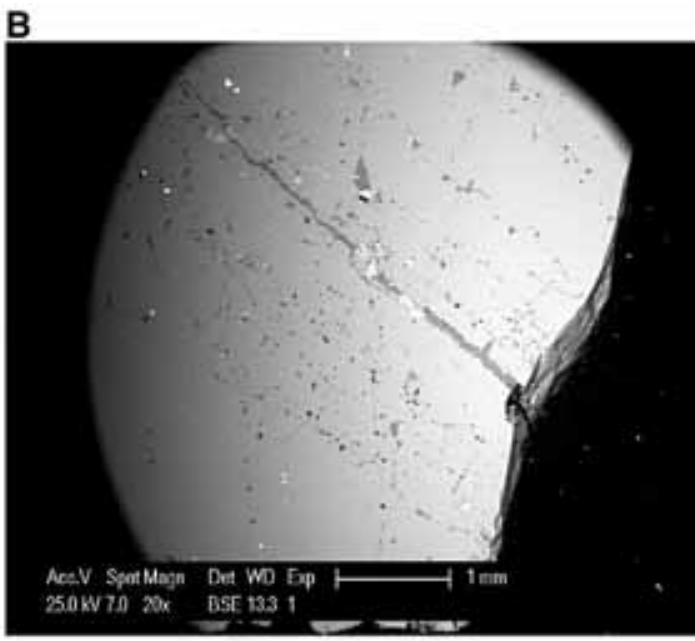

$\bar{D}$

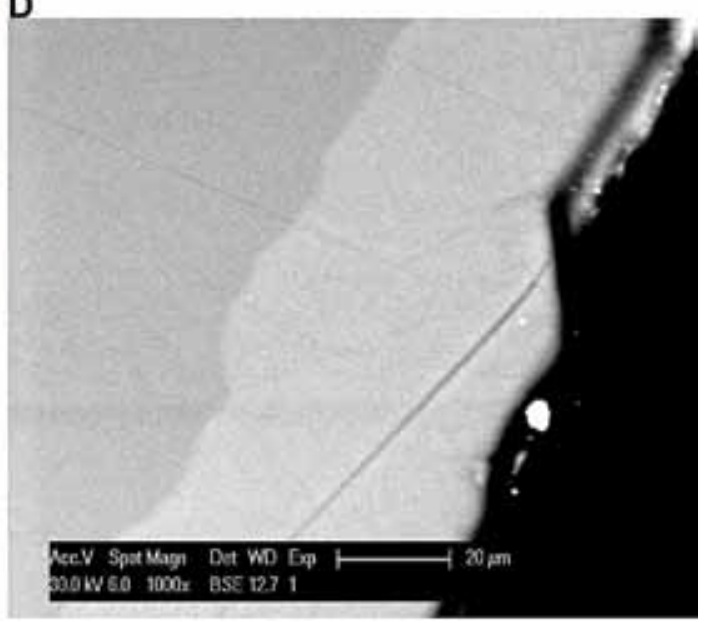

FIG. 1. A. Photograph of the OLT1 crystal. Scale bar is $4 \mathrm{~cm}$ in length. B. BSE image of OLT1 showing inclusions and infilling of fractures by other phases. Zoning was not observed using high contrast, low brightness, high accelerating potential (30 $\mathrm{kV}$ ) and extended integration-times, for most regions of the GST. The bright spots are flakes of the evaporative gold coat used to provide conductivity during the SHRIMP analysis. Scale bar is $1 \mathrm{~mm}$. C. Transmitted light image of TCB chips. Fracturing and small inclusions are visible, and the general transparency of the material is apparent. Scale bar is $3 \mathrm{~mm}$. D. High-resolution, high-contrast, high-acceleration potential $(30 \mathrm{kV}) \mathrm{BSE}$ image of the edge zone of OLT1. The edge zone has variable width and is not continuous on all faces of the GST crystals. Polishing scratches are visible as thin lines in the image. The bright spots are flakes of the evaporative gold coat used to provide conductivity during SHRIMP analysis. Scale bar is $20 \mu \mathrm{m}$.

\section{Analytical Techniques}

\section{SEM}

A selection of chips and large slices of the titanite crystals were imaged with back-scattered electrons (BSE) with a Philips XL30 scanning electron microscope (SEM) located in the Department of Imaging and Applied Physics at Curtin University of Technology
(CUT). Operating conditions were a $25 \mathrm{kV}$ accelerating voltage, an $80 \mathrm{nA}$ beam current, and a $\sim 6 \mu \mathrm{m}$ spot size.

\section{EMPA-WDS}

Electron-microprobe analyses (EMPA) were carried out with an automated JEOL JSM 6400 SEM fitted with three wavelength-dispersive crystal spectrometers (WDS), located in the Centre for Microscopy, Charac- 
terisation and Analysis (CMCA) at the University of Western Australia (UWA). Data were collected along 1-2 $\mathrm{cm}$ traverses to assess compositional variation across the crystals. Operating conditions were: accelerating voltage $20 \mathrm{kV}$, beam current $100 \mathrm{nA}$, and a spot size of $\sim 1-2 \mu \mathrm{m}$. Synthetic glasses and natural minerals were used as standards. The X-ray lines analyzed and the standard materials used for the analyses were: $\mathrm{SiK \alpha}$ (wollastonite), $\mathrm{PK} \alpha\left(\mathrm{LaPO}_{4}\right), \mathrm{Ce} L \alpha\left(\mathrm{CePO}_{4}\right), \mathrm{Sm} L \alpha$ $\left(\mathrm{SmPO}_{4}\right), \mathrm{Gd} L \alpha\left(\mathrm{GdPO}_{4}\right), \mathrm{Dy} L \alpha$ (DW4 glass), $\mathrm{Er} L \alpha$ (DW4 glass), $\mathrm{Yb} L \alpha$ (DW2 glass), $\mathrm{Y} L \alpha\left(\mathrm{YPO}_{4}\right), \mathrm{CaK} \alpha$ (wollastonite), $\mathrm{Ti} K \alpha$ (rutile), $\mathrm{Nb} L \alpha\left(\mathrm{CaNb}_{2} \mathrm{O}_{6}\right), \mathrm{Fe} K \alpha$ (Fe metal), $\mathrm{Mn} K \alpha\left(\mathrm{MnTa}_{2} \mathrm{O}_{6}\right), \operatorname{Mg} K \alpha$ (periclase), $\mathrm{Na} K \alpha$ (jadeite), $\mathrm{Al} K \alpha$ (corundum), and $\mathrm{F} K \alpha$ (fluorite). Counting times of $40 \mathrm{~s}$ were employed on both peak and background positions. Background positions were selected according to the method of Williams (1996), and overlap factors were derived empirically from measurement of the standards. The method for the analysis of titanite follows that given in Williams (1996) and Rasmussen et al. (2008). Data reduction and image manipulation used software from Moran Scientific. Uncertainties are $\pm 10 \%$ relative for minor and trace elements.

\section{Raman and photoluminescence $(P L)$ spectroscopy}

Raman and laser-induced PL spectra were obtained using a dispersive Renishaw RM1000 spectrometer system equipped with Leica DMLM optical microscope and a Si-based, Peltier-cooled charge-coupled device (CCD) detector. Spectra were excited with the blue emission of an $\mathrm{Ar}^{+}$laser $(488 \mathrm{~nm}, \sim 10 \mathrm{~mW}$ at the sample surface). A $50 \times$ objective (numerical aperture 0.75 ) was used to focus the laser beam onto the sample surface. Spectra were obtained in the quasi-confocal mode, with a lateral resolution of $\sim 4-5 \mathrm{~mm}$. The laser energy used (or, more precisely, the energy density) was well below the threshold where intense heating of samples by local absorption of the laser light produces sample chemical or structural changes. The spectral resolution was $\sim 5 \mathrm{~cm}^{-1}$, which corresponds to between $0.07 \mathrm{~nm}$ in the blue and $0.28 \mathrm{~nm}$ in the near-infrared range. Spectra were calibrated using Ne lamp emissions, and the wavenumber accuracy was better than $1 \mathrm{~cm}^{-1}$ (i.e., clearly better than $0.1 \mathrm{~nm}$ ). For more experimental details, see Nasdala \& Massonne (2000).

\section{Electron-backscatter diffraction (EBSD)}

Chips of the titanite samples were analyzed by electron-backscatter diffraction at the Micro-structural Analysis Facility, Curtin University of Technology. Data acquisition, processing and post-processing analysis of the EBSD data were undertaken using a XL-30 Philips SEM and Oxford Instruments Channel 5.9 software using settings described elsewhere (Reddy et al. 2007). Empirical electron-backscatter spectra were obtained from $150 \times 150 \mu \mathrm{m}^{2}$ areas of several of chips of each sample of titanite, and were used to produce maps of EBSP quality and crystallographic orientation. Noise reduction from spurious pixels included a "wild-spike" and four-nearest neighbor zero-solution correction (Reddy et al. 2008).

\section{SHRIMP $U-T h-P b$ analysis}

Titanite chips and slices were mounted and polished in epoxy mounts $2.5 \mathrm{~cm}$ in diameter, and then goldcoated prior to SEM imaging and analysis on the Sensitive High mass-Resolution Ion Microprobe (SHRIMP). The Khan titanite was used as the principal RM for $\mathrm{Pb}^{*} / \mathrm{U}$ and $\mathrm{Th} * / \mathrm{Pb}$ calibration as it has been well characterized by TIMS analysis (Heaman 2009). The SHRIMP analyses were conducted on the two SHRIMP II ion probes at Curtin University. Our datasets were collected between August 2006 and October 2009. The initial analytical sessions were aimed at identifying possible U-Pb RM, whereas later datasets were aimed at characterizing the most likely candidates. The titanite data are from nine SHRIMP analytical sessions on six different mounts. Analytical sessions for an initial assessment consisted of measurements of the Khan titanite interspersed with multiple analyses of multiple chips of one or more of the Grenville skarn titanite, plus other titanite grains. In later characterization sessions, large chips or single slices of a single crystal of titanite were analyzed, along with a smaller number of reference standard analyses. The SHRIMP data are processed with SQUID2 (Ludwig 2009). The calculated ages and concordia diagrams rely on the ${ }^{238} \mathrm{U}$ decay constant of Jaffey et al. (1971), $1.55125 \times 10^{-10}$, and the revised ${ }^{235} \mathrm{U}$ decay constant of Schoene et al. (2006), $9.8569 \times$ $10^{-10}$. Common $\mathrm{Pb}$ compositions are calculated from the Stacey \& Kramers (1975) bulk-crust Pb isotope composition model. Statistical parameters and Concordia diagrams were generated with Isoplot 3 (Ludwig 2003).

One possible difficulty faced in using the SHRIMP data to assess the homogeneity of the titanite samples is the use of the Khan titanite as the principal RM, as this titanite crystal shows some heterogeneity at the scale of the TIMS analytical volume (Kinny 1997, Heaman 2009). This introduces an additional level of uncertainty to the datasets. However, we have treated the Khan chips as being homogeneous for our data reduction, and we have seen no evidence for large isotopic variations. For one dataset, we used OLT2 as the RM for analysis of TCB, as the chip of Khan intended for use as the RM was ground away during mount polishing. The possible slight heterogeneity of our Khan titanite chips makes the identification of subtle matrix effects or orientation effects difficult. However, small differences between standard chips can easily account for any subtle differences in the final datasets from different mounts.

Additional details of the SHRIMP analytical technique are given in Appendix 1. 


\section{TIMS}

The uranium-lead ID-TIMS ages of the Grenville skarn titanite crystals were determined in the Jack Satterly Geochronology Laboratory at the University of Toronto based on procedures modified from Krogh (1973). Fragments of titanite crystals were weighed on a microbalance, cleaned in $2 \mathrm{~N} \mathrm{HNO}_{3}$, and rinsed with water and then acetone. The crystals were placed into $3 \mathrm{~mL}$ Teflon capsules with $\sim 300 \mu \mathrm{L}$ of concentrated $\mathrm{HF}, \sim 40 \mu \mathrm{L}$ of $8 \mathrm{~N} \mathrm{HNO}_{3}$, and a measured quantity of a ${ }^{205} \mathrm{~Pb}-{ }^{235} \mathrm{U}$ spike solution. The capsules were placed on a hot plate at $\sim 80^{\circ} \mathrm{C}$ for $\sim 5$ days, and following this, the solution was dried to a precipitate and then redissolved in $\sim 0.3 \mathrm{~mL}$ of $3 \mathrm{~N} \mathrm{HCl}$ on a hot plate at $\sim 80^{\circ} \mathrm{C}$ overnight. Uranium and $\mathrm{Pb}$ were isolated from the titanite solution using $\mathrm{HBr}$ and anion-exchange chromatography, dried down with $\sim 0.010 \mathrm{~mL}$ of $0.05 \mathrm{~N} \mathrm{H}_{3} \mathrm{PO}_{4}$, and deposited onto outgassed single rhenium filaments with silica gel (Gerstenberger \& Haase 1997). Lead and U were characterized with a VG354 mass spectrometer using multiple Faraday collectors in multidynamic collection mode for $\mathrm{Pb}$ (i.e., alternating ${ }^{205} \mathrm{~Pb}$ and ${ }^{204} \mathrm{~Pb}$ in the axial Daly collector) and static collection for $\mathrm{U}$, or in some cases a Daly detector in pulse-counting mode for smaller samples of $U$. Dead time of the measuring system for $U$ was $21 \mathrm{~ns}$. The correction for the Daly detector bias is constant at $0.05 \%$ per atomic mass unit. Amplifier gains were monitored using the SRM982 $\mathrm{Pb}$ standard. A thermal mass-fractionation correction of $0.10 \%$ per atomic mass unit was used, with errors of $0.08 \%$ and $0.05 \%(2 \sigma)$ for $\mathrm{Pb}$ and $\mathrm{U}$, respectively. Initial common $\mathrm{Pb}$ in excess of estimated blanks of 2 and $0.1 \mathrm{pg}$ for $\mathrm{Pb}$ and $\mathrm{U}$, respectively, was corrected by using the Stacey \& Kramers (1975) model. The spike calibration-error on the ratio $\mathrm{U} / \mathrm{Pb}$ is $0.1 \%(2 \sigma)$. Decay constants are those of Jaffey et al. (1971). All age errors quoted in this article and error ellipses in the concordia diagrams are given at the $95 \%$ confidence interval. Plotting and age calculations were done using Isoplot 3.00 (Ludwig 2003).

\section{RESULTS}

Titanite can have complex internal zoning, as shown by BSE imaging, and small grains of titanite from the southwestern area of the Grenville Province have isotopic compositions that are partially or completely reset (Ketchum et al.1998). Therefore, we have ensured that our data are from both the interior and outer regions of the GST crystals.

\section{SEM}

The SEM images (Figs. 1B, D) show that the GST crystals exhibit fracturing, contain inclusions, and exhibit minor alteration along some cracks. Although chips of the GST are transparent (Fig. 1C), SEM examination shows that they cannot be used as RM for bulk techniques. Careful hand-picking of finely crushed material is essential for TIMS analysis, and with microanalysis techniques, one must select inclusion-free, unaltered material, and use transmitted light and electron microscope examination prior to analysis.

\section{EMPA-WDS results}

Results of electron-microprobe WDS analyses of chips and slices of the titanite samples are given in Table 1. The GST samples have high contents of $\mathrm{Al}_{2} \mathrm{O}_{3}$, $\mathrm{FeO}, \mathrm{Nb}_{2} \mathrm{O}_{5}$ and $\mathrm{F}$. The amount of $\mathrm{TiO}_{2}$ is well below the $40.7 \mathrm{wt} \%$ of pure $\mathrm{CaTiSiO}_{5}$, suggesting octahedral substitution of $\mathrm{Al}, \mathrm{Fe}$ and $\mathrm{Nb}$ for Ti. The high $\mathrm{Al}_{2} \mathrm{O}_{3}$, $\mathrm{FeO}, \mathrm{Nb}_{2} \mathrm{O}_{5}$ and $\mathrm{F}$ contents of the GST crystals examined in this study are typical of titanite from other Grenville skarns (Shaw 1958, Frei et al. 1997), and typical of titanite formed during upper amphibolitefacies metamorphism (Frei et al. 1997, Ketchum et al. 1998, Tropper \& Manning 2008) but very much higher than most titanite from granitic rocks (Frost $e t$ al. 2001). Titanite from granitic pegmatites commonly have elevated levels of $\mathrm{Al}_{2} \mathrm{O}_{3}, \mathrm{REE}, \mathrm{FeO}, \mathrm{Nb}_{2} \mathrm{O}_{5}$, and $\mathrm{F}$, but rarely do they reach levels similar to those of the GST. For example, the Khan titanite, of pegmatite origin (Table 1), which has elevated levels of substitution compared to titanite from granitic and mafic rocks (e.g., Paterson \& Stephens 1992), has lower levels of these components than the GST. The GST have $\mathrm{CaO}$ that is close to $28 \mathrm{wt} \%$, a value that is slightly below that of the pure stoichiometric compound, $28.5 \mathrm{wt} \%$, and this can be explained by substitution of the rare-earth elements for calcium. Our EMP analyses were characterized by totals close to $100 \%(98.8-100.8$ wt \%). There is thus very little evidence for the coupled substitution of $\mathrm{Ti}^{4+}$ $+\mathrm{O}^{2-}=\mathrm{A}^{3+}+\mathrm{OH}^{-}$that produces low totals in some samples of titanite (Franz \& Spear 1985). Our GST materials typically have an excess of approximately $5 \%$ of the octahedrally coordinated cations, such as $\mathrm{Ti}$, $\mathrm{Al}, \mathrm{Fe}$, and $\mathrm{Nb}$. This is usually explained by $4+$ ions substituting for $\mathrm{Si}^{4+}$ at the tetrahedral sites (Hollabaugh $\&$ Rosenberg 1983). However, the $\mathrm{SiO}_{2}$ concentrations of the GST are close to $30 \mathrm{wt} \%$, as would be expected for pure, stoichiometric $\mathrm{CaTiSiO}_{5}$. It is thus unlikely that there is significant substitution of ${ }^{\mathrm{IV}} \mathrm{Ti}$ at the $\mathrm{Si}$ site.

The data from the series of EMP analyses across slices of the OLT1, OLT2 and TCB titanite crystals are shown in Figure 2. Table 1 contains mean compositions and standard deviations for analyses from the Interior, Rim and Edge zones for each of the GST crystals. We use this three-fold terminology, based on the EMP data, to compare different parts of the crystallization history of these large crystals. The Interior zone represents the first-formed material and encompasses the center of the crystal and a zone extending outward to the inner edge of the Rim zone. The Rim is defined as a zone $5 \mathrm{~mm}$ wide immediately adjacent to the Edge zone. These 
TABLE 1. MEAN RESULTS OF ELECTRON-MICROPROBE ANALYSES (WDS) OF THE INTERIOR, RIM AND OUTER EDGE ZONES OF THE CRYSTALS OF GRENVILLE SKARN TITANITE

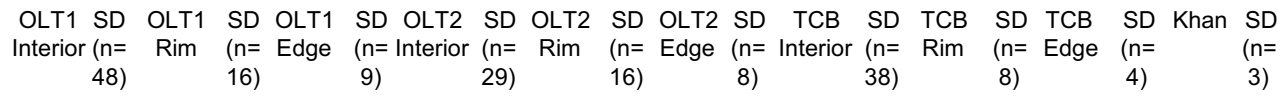

\begin{tabular}{|c|c|c|c|c|c|c|c|c|c|c|c|c|c|c|c|c|c|c|c|c|}
\hline $\mathrm{iOO}_{2} \mathrm{wt} \%$ & 30.48 & 0.27 & 30.87 & 0.25 & .24 & 0.10 & 30.88 & 0.323 & .0 & 0.2 & 12 & 0.0 & 81 & 0. & 30.65 & & .09 & & & \\
\hline $\mathrm{iO}_{2}$ & 29.98 & 0.21 & 30.76 & 0.48 & 30.53 & 0.36 & 29.81 & 0.50 & .76 & 0.35 & .57 & 0.59 & .50 & 0. & 1.03 & 0.46 & 31.02 & 0. & .77 & \\
\hline $\mathrm{b}_{2} \mathrm{O}_{5}$ & 0.76 & 0.04 & 0.32 & 0.04 & 0.20 & 0.03 & 0.29 & 0.04 & 0.25 & 0.02 & 0.27 & 0.03 & 0.26 & 0.03 & 0.24 & 0.04 & 0.20 & 0.03 & 0.55 & \\
\hline${ }_{2} \mathrm{O}_{3}$ & 0.19 & 0.03 & 0.23 & 0.04 & 0.30 & 0.05 & 0.23 & 0.03 & 0.21 & 0.01 & 0.24 & 0.04 & 0.29 & 0.04 & 0.30 & 0.04 & .32 & 0.02 & 0.39 & \\
\hline $\mathrm{Ce}_{2} \mathrm{O}_{3}$ & 0.44 & 0.04 & 0.44 & 0.04 & 0.50 & 0.05 & 0.42 & 0.02 & 0.33 & 0.29 & 0.42 & 0.03 & 0.54 & 0.06 & 0.52 & 0.03 & .57 & 0.01 & 0.76 & \\
\hline $\mathrm{Sm}_{2} \mathrm{O}_{3}$ & 0.08 & 0.04 & 0.09 & 0.03 & 0.09 & 0.05 & 0.07 & 0.03 & 0.06 & 0.03 & 0.07 & 0.03 & 0.10 & 0.04 & 0.11 & 05 & 07 & 05 & 0.10 & \\
\hline $\mathrm{Gd}_{2} \mathrm{O}_{3}$ & 0.08 & 0.04 & 0.11 & 0.04 & 0.09 & 0.06 & 0.08 & 0.03 & 0.08 & 0.03 & 0.08 & 0.03 & 0.09 & .04 & 0.10 & 03 & 13 & 04 & 0.11 & \\
\hline $\mathrm{y}_{2} \mathrm{O}_{3}$ & 0.03 & .02 & 0.04 & 0.03 & 0.05 & 0.03 & 0.02 & 0.02 & 0.03 & 0.02 & 0.03 & 0.02 & 0.04 & 02 & 0.06 & 03 & .06 & 00 & 0.02 & \\
\hline $\mathrm{r}_{2} \mathrm{O}_{3}$ & 0.02 & .02 & 0.02 & 0.03 & 0.03 & 0.02 & 0.03 & 0.02 & 0.03 & 0.02 & 0.03 & 0.02 & 0.03 & 02 & 0.03 & 0.02 & .06 & 02 & 0.04 & \\
\hline $\mathrm{Yb}_{2} \mathrm{O}_{3}$ & 0.01 & 0.02 & 0.01 & 0.01 & 0.01 & 0.01 & 0.01 & 0.02 & 0.02 & 0.01 & 0.01 & 0.01 & 0.01 & .02 & 0.03 & 0.02 & .03 & 0.02 & 0.01 & \\
\hline $\mathrm{Al}_{2} \mathrm{O}_{3}$ & 5.47 & 0.05 & 6.20 & 0.18 & 7.09 & 0.25 & 6.79 & 0.13 & 6.80 & 0.06 & 6.82 & 0.08 & 5.79 & 0.19 & 6.08 & 0.22 & 6.48 & 0.04 & 3.02 & \\
\hline $\mathrm{eO}$ & 2.62 & 0.07 & 1.64 & 0.09 & 0.97 & 0.03 & 1.61 & 0.04 & 1.62 & 0.02 & 1.61 & 0.03 & 1.21 & 04 & 1.15 & 0.05 & 1.18 & 0.04 & 1.52 & \\
\hline $\mathrm{MnO}$ & 0.04 & 0.01 & 0.05 & 0.01 & 0.04 & 0.01 & 0.05 & 0.01 & 0.04 & 0.01 & 0.05 & 0.01 & 0.05 & 0.02 & 0.04 & 0.01 & 0.04 & 0.01 & 0.14 & \\
\hline $\mathrm{MgO}$ & 0.01 & 0.01 & 0.08 & 0.01 & 0.17 & 0.01 & 0.08 & 0.01 & 0.09 & 0.01 & 0.10 & 0.01 & 0.12 & 0.01 & 0.12 & 0.01 & 0.14 & 0.01 & 0.00 & \\
\hline $\mathrm{aO}$ & 28.12 & 0.24 & 28.67 & 0.24 & 28.19 & 0.222 & 28.55 & 0.37 & 27.79 & 0.45 & 28.31 & 0.112 & 27.70 & 0.43 & 27.47 & 0.462 & 28.20 & 0.24 & 27.53 & \\
\hline $\mathrm{a} 2 \mathrm{O}$ & 0.01 & 0.00 & 0.01 & 0.00 & 0.01 & 0.00 & 0.01 & 0.00 & 0.01 & 0.00 & 0.01 & 0.00 & 0.01 & 0.01 & 0.01 & 0.00 & 0.01 & 0.00 & 0.01 & 0.0 \\
\hline & 1.61 & 0.13 & 1.82 & 0.16 & 2.36 & 0.20 & 1.23 & 0.14 & 2.28 & 0.13 & 2.25 & 0.14 & 1.45 & 0.10 & 1.35 & 0.11 & 2.17 & 0.02 & 0.75 & 0.0 \\
\hline $\mathrm{P}_{2} \mathrm{O}_{5}$ & 0.10 & .02 & 0.14 & 0.02 & 0.20 & 0.01 & 0.19 & 0.02 & 0.10 & 0.02 & 0.16 & 0.01 & 0.10 & 0.01 & 0.10 & 0.01 & 0.24 & 0.02 & 0.19 & \\
\hline Total & 00.04 & .561 & 01.48 & 0.671 & 01.08 & 0.44 & 00.36 & 0.801 & 01.24 & 94 & 00.13 & 0.58 & 00.11 & 0.59 & 99.34 & 0.531 & 00.99 & 0.01 & 99.50 & .2 \\
\hline \multirow[t]{2}{*}{$\mathrm{O} \equiv \mathrm{F}$} & 0.68 & & 0.77 & & 0.99 & & 0.52 & & 0.96 & & 0.95 & & 0.61 & & 0.57 & & 0.91 & & 0.32 & \\
\hline & 99.36 & & 1 & & 00.09 & & 99.84 & & 00.28 & & (3.1. & & 99.50 & & 98.71 & & 00.60 & & प्. 1 & \\
\hline
\end{tabular}

compositions are representative of the bulk of the material grown during crystallization. The Edge zone refers to data acquired in the outer $200 \mu \mathrm{m}$ of the crystal, and it represents material grown at the final stage of skarn development.

Reference material OLT1 exhibits a range of compositions for the major elements and a rapid change in composition close to the outer edge of the crystal. The $\mathrm{Al}_{2} \mathrm{O}_{3}$ and $\mathrm{F}$ contents increase from the core to the outer edge of the crystal, with ranges of 5.4 to $7.1 \mathrm{wt} \%$, and 1.5 to $2.0 \mathrm{wt} \%$, respectively. The constituents $\mathrm{FeO}$ and $\mathrm{Nb}_{2} \mathrm{O}_{5}$ show the opposite trend from the core to outer edge, with ranges of 2.6 to $1.0 \mathrm{wt} \%$, and 0.8 to $0.2 \mathrm{wt} \%$, respectively. Reference material OLT2 has the same core-to-outer-edge trends as OLT1, but with reduced ranges, and therefore, a less heterogeneous composition (Fig. 2). The component $\mathrm{Al}_{2} \mathrm{O}_{3}$ is higher in OLT2 than OLT1 and TCB, and varies from $6.2 \%$ to $6.8 \%$ over a distance of $2.7 \mathrm{~cm}$. Fluorine varies from $1.9 \%$ in the core to $2.4 \%$ near the edge of the crystal. The component $\mathrm{FeO}$ varies from $1.9 \%$ in the core to $1.6 \%$ at the edge, and $\mathrm{Nb}_{2} \mathrm{O}_{5}$ decreases slightly from $0.29 \%$ to $0.23 \%$. Reference material OLT2 does not exhibit the rapid compositional changes near the outer edge that are shown by OLT1 and TCB. Reference material TCB exhibits the same trends as OLT1, including the rapid change in composition close to the outer edge of the crystal; this sample has much lower FeO in the core than OLT1.

The GST materials are enriched in trace elements and the LREE are enriched relative to the HREE. For example, our maximum WDS-established $\mathrm{Ce}_{2} \mathrm{O}_{3}$ content is $0.53 \mathrm{wt} \%$. This equates to $4525 \mathrm{ppm} \mathrm{Ce}$. Similarly, the heavier REE are enriched, but to a slightly lesser degree. For example, $\mathrm{Dy}_{2} \mathrm{O}_{3}$ has a maximum value of $0.06 \mathrm{wt} \%$, which equals $523 \mathrm{ppm}$. These levels of the REE are typical of what is observed for titanite from granites (Marks et al. 2008), and LREE/HREE > 1 would be predicted from partitioning studies of titanite (Prowatke \& Klemme 2005). The REE data from the EMPA-WDS traverses across the GST crystals do not show the consistent trends shown by $\mathrm{Al}_{2} \mathrm{O}_{3}, \mathrm{FeO}, \mathrm{F}$ and $\mathrm{Nb}_{2} \mathrm{O}_{5}$, with only minor variation outside of analytical uncertainties.

The WDS data show that (1) none of the GST are homogeneous in major or trace elements, (2) there is chemical variation that is larger than the analytical precision for the elements displayed, (3) the Edge zone can be enriched or depleted, relative to the Interior and Rim zones of the crystals, (4) there is a slow consistent variation in composition over large distances within the Interior and Rim zones of the crystal, (5) each crystal has a slightly different composition, and (6) there are occasional large steps in composition between adjacent WDS analyses. 

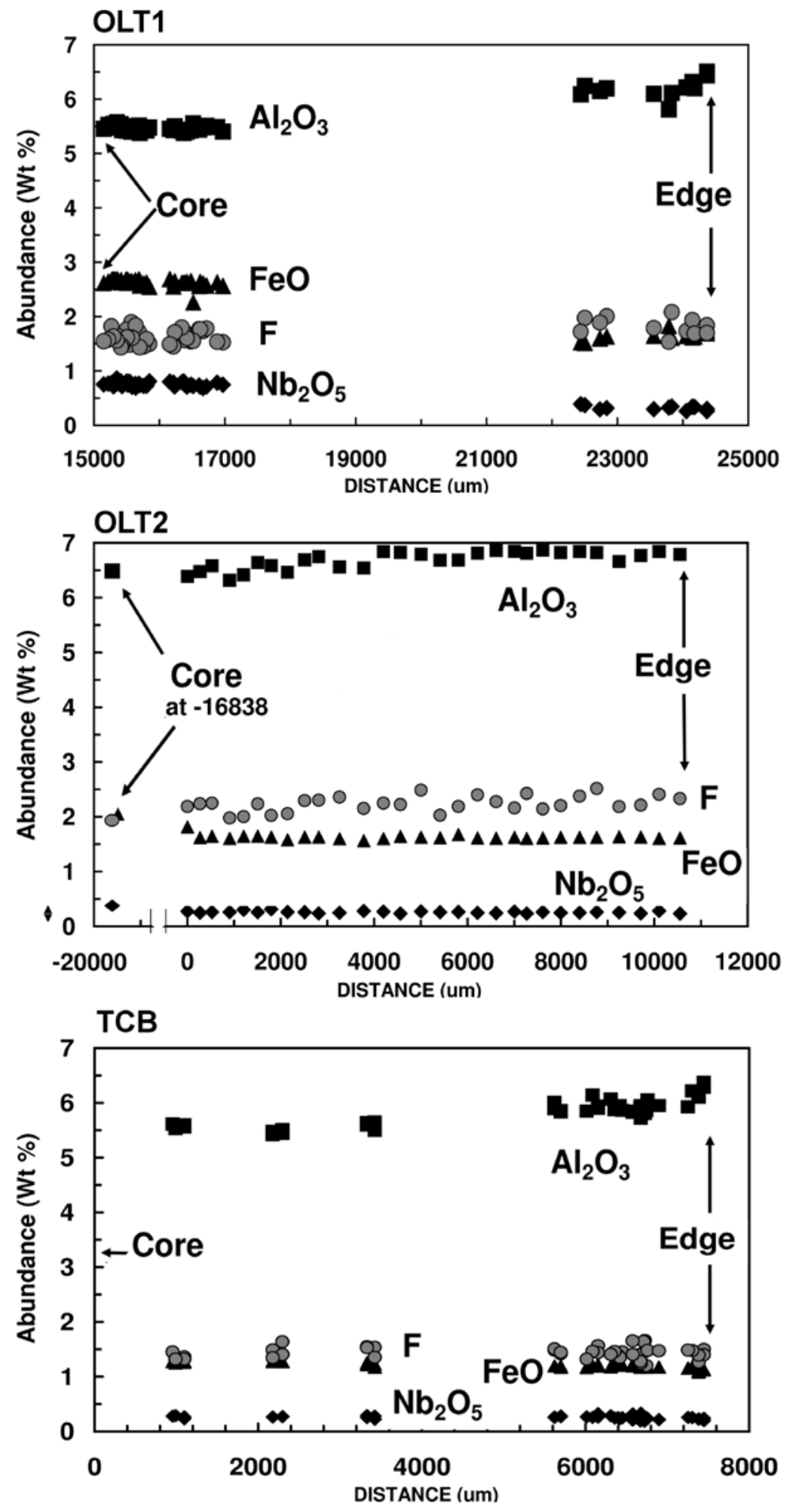
The observed internal compositional variation of the GST is typical of titanite, a mineral that commonly displays complex sector-zoning (Paterson \& Stephens 1992) and widely varying levels of substitution (Frost $e t$ al. 2001, Seifert 2005, Prowatke \& Klemme 2005). The GST exhibit too much chemical variation to be useful as electron-microprobe standards.

\section{Radiation damage and spectroscopy}

The present $\mathrm{U}$ and $\mathrm{Th}$ concentrations and age of a mineral can be used to calculate a time-integrated alpha fluence $\left(D_{\alpha}\right)$ [see Murakami et al. (1991) for the equation], and this value can be used in comparisons of the expected radiation-induced damage of the different titanite materials and other minerals. The calculated $\mathrm{D}_{\alpha}$ values for OLT1, OLT2, TCB and Khan are respectively, $1.73 \times 10^{18} \alpha / \mathrm{g}, 1.33 \times 10^{18} \alpha / \mathrm{g}, 1.80 \times 10^{18} \alpha / \mathrm{g}$, and $1.22 \times 10^{18} \alpha / g$. These values of $D_{\alpha}$ are comparable to the values for most Sri Lankan zircon SIMS standards (e.g., Br266, $1.83 \times 10^{18} \alpha / \mathrm{g}, \mathrm{CZ} 3,1.08 \times 10^{18} \alpha / \mathrm{g}$, M257, $1.66 \times 10^{18} \alpha / g ; c f$. Nasdala et al. 2008) and are low when compared with the $\mathrm{D}_{\alpha}$ value of $\sim 10^{19}$ alpha-events per gram calculated for nearly amorphous Sri Lankan zircon (Weber et al. 1994, Nasdala et al. 2004). The comparably low self-irradiation doses of all titanite samples suggest that even if the samples did not experience any low-T thermal annealing since the time of their primary formation (which remains uncertain), they cannot have accumulated a large amount of radiation damage.

There are several ways to study quantitatively the radiation damage in minerals using micro-spectroscopy. In Raman spectra, the degree of accumulated damage can be estimated from the broadening of vibrational bands [shown in detail for zircon by Nasdala et al. (1995)]. It should be noted, however, that an increase of the band width (expressed by the full width at band half-maximum, FWHM) may also be due to other structural effects such as strain, and the sample's chemical composition, especially if elevated concentrations of non-formula elements are incorporated. To give an example of the latter effect, Seydoux-Guillaume et al. (2002) determined the FWHM of the main internal phosphate band $\left[v_{1}\left(\mathrm{PO}_{4}\right)\right.$ near $\left.970 \mathrm{~cm}^{-1}\right]$ of an annealed sample of natural monazite at $\sim 7 \mathrm{~cm}^{-1}$, whereas the $v_{1}\left(\mathrm{PO}_{4}\right)$ FWHM of chemically pure monazite is $\sim 2$ $\mathrm{cm}^{-1}$ (Nasdala et al. 2010). In view of this finding,

FIG. 2. Abundances of $\mathrm{Al}_{2} \mathrm{O}_{3}, \mathrm{FeO}, \mathrm{F}$ and $\mathrm{Nb}_{2} \mathrm{O}_{5}$ (wt $\%$ ) measured by WDS-EMP analysis along slices of titanite. A. OLT1, B. OLT2, and C. TCB. Distance along the abscissa is in $\mu \mathrm{m}$.
FWHM values of Raman bands can only be used for accurate quantitative estimates of the degree of the radiation damage if (1) a reliable calibration of radiation effects on the Raman spectrum is available, and (2) the chemical FWHM increase is either minor (such as in the case of zircon) or well calibrated. Both factors are not the case for titanite.

In general, the Raman spectra of the GST and other titanite samples do not show as well-defined bands as the spectra of synthetic $\mathrm{CaTiSiO}_{5}$ and a crystalline reference titanite ( $c f$. Meyer et al. 1996). In particular, samples OLT1, OLT2, and TCB yielded notably broadened vibrational bands (Fig. 3). This indicates a disturbed short-range order, which can, as discussed above, be due to radiation damage or chemical substitution at the percentage level of such elements as $\mathrm{Fe}, \mathrm{F}$, and Al. However, it is impossible to quantify from the Raman spectra alone whether the bands are broadened by an especially "colorful" composition, or radiation damage, or both, but it appears that samples TITQUEBEC, TSMLC, and KT are less disordered than TCB and the two OLT samples. All samples, however, seem to be not more than mildly to moderately radiation-damaged. If the GST were metamict, the Raman spectra would be similar to that of glassy titanite shown in Figure 3A (compare also Zhang \& Salje 2003, Bismayer et al. 2010).

Another method of studying radiation damage in accessory minerals is based on the fine-splitting of electronic transitions of $\mathrm{REE}^{3+}$-related emission centers due to crystal-field effects. Increasing radiation-induced damage can be probed using the broadening of individual $\mathrm{REE}^{3+}$ sub-bands in luminescence spectra. For instance, Panczer et al. $(2003,2005)$ proposed to use the ${ }^{4} \mathrm{~F}_{3 / 2} \rightarrow{ }^{4} \mathrm{I}_{9 / 2}$ transition of $\mathrm{Nd}^{3+}$ in evaluating the radiation damage of monazite.

The laser-induced photoluminescence spectra of all the GST and other titanite samples in Figure 3B are similar, as expected, as the samples have all incorporated the same group of rare-earth elements. The group of narrow bands between 600 and $660 \mathrm{~nm}$ wavelength is mainly due to $\mathrm{Sm}^{3+}$ and $\mathrm{Er}^{3+}$ (perhaps also $\mathrm{Pr}^{3+}$ ), and the group of bands above $840 \mathrm{~nm}$ is due to $\mathrm{Nd}^{3+}$ (Gaft et al. 2005). The broad background feature in the red to nearinfrared range $(700-870 \mathrm{~nm})$ is most likely assigned to an emission center with a $3 \mathrm{~d}$ electronic configuration, such as $\mathrm{Fe}^{3+}$ or $\mathrm{Cr}^{3+}$. In general, the REE-related electronic transitions show a well-developed fine-splitting, with minor variations of their moderate broadening of the individual emission sub-bands. For example, the intense, narrow $\mathrm{Sm}^{3+}$ band near $602 \mathrm{~nm}\left({ }^{4} \mathrm{G}_{7 / 2} \rightarrow{ }^{6} \mathrm{H}_{7 / 2}\right.$ transition) is somewhat broader in the TCB spectrum, compared to the TSMCL spectrum (FWHM 2.6 and 1.9 $\mathrm{nm}$, respectively). The difference is probably due to a more complex composition of TCB, with only a minor contribution of low levels of radiation damage.

In summary, the Raman and PL spectra show discernable, but minor differences among the different 

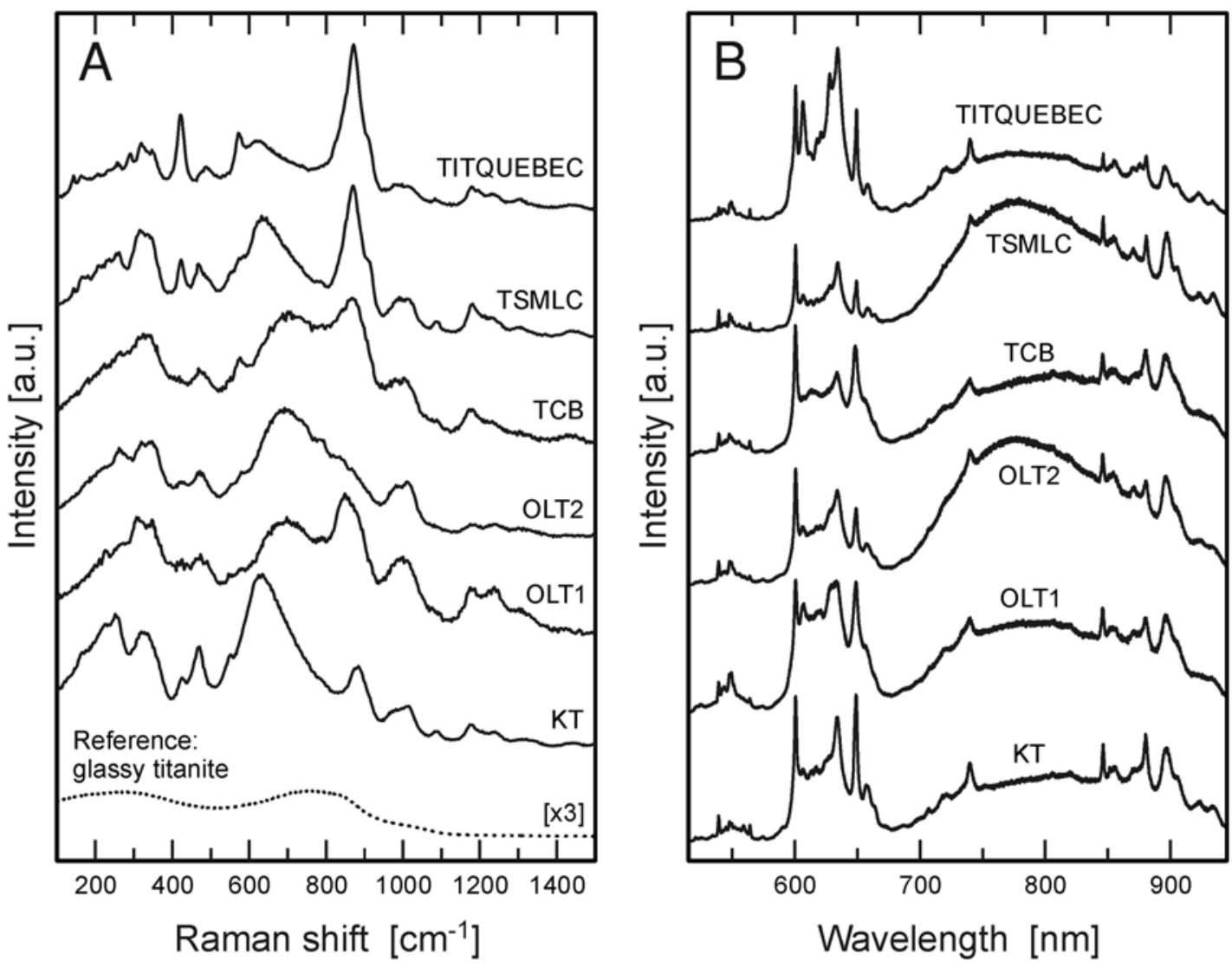

FIG. 3. A. Raman spectra of GST and the Khan titanite (KT), in comparison to the reference spectrum of a glass of titanite composition produced by quenching of melt. The different relative intensities of the bands in the spectra should not be considered important, as this results from the random crystallographic orientation of samples. B. Corresponding laser-induced PL emission spectra (488 nm excitation). Spectra are dominated by groups of emission bands of REE centers (for band assignment, see Gaft et al. 2005). The average concentrations of actinides in the samples (in ppm) are: TITQUEBEC: U 70, Th 151, TSMLC: U 46, Th 120, TCB: U 295, Th 620, OLT2: U 252, Th 539, OLT1: U 335, Th 637, KT, U 584, Th 1100.

GST, and between the GST and low-U titanite. These differences are attributed to both chemical variations and minor radiation damage. The Raman and PL spectra confirm the mild to moderate radiation-damaged state of the Grenville skarn titanite and their complex chemical composition, and show that they have a slightly more disordered state than the Khan titanite. This is as expected, as the Khan titanite has lower levels of Fe, $\mathrm{Al}, \mathrm{F}$, and Th, and a lower calculated $\mathrm{D}_{\alpha}$ than the GST.

\section{Results from electron-backscatter diffraction (EBSD)}

Our EBSD analysis has been used to assess the amount of misorientation present at the length scale of SIMS analysis (Timms et al. 2006). We also use electron-backscatter diffraction patterns (EBSP) to qualitatively examine the degree of radiation damage present in individual chips (Nemchin et al. 2009). In addition, we have used EBSD to assess whether there is a crystallographic orientation effect on secondary ion sputtering that is similar to that observed in baddeleyite (Wingate \& Compston 2000).

Our EBSD analysis of five millimetric chips of OLT1, eight chips of OLT2, and one chip of TCB show an even quality of pattern and very little variation in orientation within each chip (Fig. 4). In two chips of OLT1, there were small patches $20-100 \mu \mathrm{m}$ across that show $\sim 3^{\circ}$ misorientation relative to the rest of the chip. The well-defined EBSPs of the GST materials are consistent with low degrees of metamictization from radiation damage. The quality (strength of diffraction bands) of the EBSPs show that there are similar degrees of radiation damage in the different chips of each titanite sample, and among the three GST titanite 
samples. We found no systematic relationship between the crystallographic orientation of the GST chips with respect to the incident SHRIMP beam and SHRIMP $\mathrm{U}-\mathrm{Pb}$ data. Our data show that any orientation effect is small relative to other analytical uncertainties. The EBSD results show that there is no significant internal crystallographic misorientation, and the SIMS data for the GST are unaffected by deformation-related traceelement diffusion (Reddy et al. 2007).

\section{SHRIMP $U-T h-P b$ analysis}

Analytical results for the individual sessions are given in Table 2, and the results of the sessions characterizing OLT1, OLT2, and TCB are described below. Data arising from individual analyses are presented in the table of Supplemental Data, which is available from the Depository of Unpublished Data on the MAC website [document Grenville titanite CM48_1423]. Figure 5 shows a Wetherill concordia plot for the three GST samples, in which the analytical results of multiple sessions on each sample have been combined. All individual analyses are concordant given our $2 \sigma$ uncertainties. The data for OLT1, OLT2 and TCB are very consistent; very few results of analyses plot outside the principal groups.

Eighty-eight analyses of OLT1, made over four analytical sessions, give a concordia age of 1016.8 $\pm 3.8 \mathrm{Ma}$ (Fig. 5A), the MSWD for concordance is 3.5 , with a probability of concordance of 0.062 . The
MSWD for concordance and equivalence is 0.85 , with a probability of 0.92 . The Tukey's bi-weighted mean ${ }^{206} \mathrm{~Pb} * /{ }^{238} \mathrm{U},{ }^{207} \mathrm{~Pb}^{*}{ }^{206} \mathrm{~Pb}^{*}$ and ${ }^{208} \mathrm{~Pb} * / 232 \mathrm{Th}$ ages for OLT1 are respectively, $1015.9 \pm 4.1 \mathrm{Ma}, 1017.1 \pm 7.3$ $\mathrm{Ma}$, and $1019.3 \pm 6.6 \mathrm{Ma}$, where the uncertainties are $95 \%$ confidence limits.

Fifty-four analyses of OLT2 from three sessions give a concordia age of $998.3 \pm 6.1 \mathrm{Ma}$ (Fig. 5B); the MSWD of concordance is 4.8 , with a probability of concordance of 0.029 . The MSWD for concordance and equivalence is 0.56 , with a probability of 1.00 . The Tukey's bi-weighted mean ${ }^{206} \mathrm{~Pb} * / 238 \mathrm{U},{ }^{207} \mathrm{~Pb} * / 206 \mathrm{~Pb}^{*}$ and ${ }^{208} \mathrm{~Pb} * 232 \mathrm{Th}$ ages for OLT2 are, respectively, 997.7 $\pm 5.1 \mathrm{Ma}, 1010 \pm 11 \mathrm{Ma}$, and $1003 \pm 7.3 \mathrm{Ma}$, where the uncertainties are $95 \%$ confidence limits.

The data derived from the seventy-six analyses of TCB, from three sessions are listed in Table 2. There is sufficient scatter in this dataset that a concordant age cannot be calculated using Isoplot without eliminating data. Two "older" points from the first analytical session must be removed before a concordia age can be calculated if the ${ }^{204} \mathrm{~Pb}$-corrected data are used. The resultant concordia age is $1021.8 \pm 2.4 \mathrm{Ma}(95 \%$ confidence limit), MSWD $=1.6$, with a probability of concordance of 0.21 . The MSWD for concordance and equivalence is 1.08 , with a probability of 0.24 . The Tukey's bi-weighted mean ${ }^{206} \mathrm{~Pb} * / 238 \mathrm{U},{ }^{207} \mathrm{~Pb} * / 206 \mathrm{~Pb}^{*}$ and ${ }^{208} \mathrm{~Pb} * / 232 \mathrm{Th}$ ages for TCB are, respectively, 1022.2 $\pm 3.0 \mathrm{Ma}, 1024.1 \pm 5.1 \mathrm{Ma}$, and 1016.2 $\pm 4.7 \mathrm{Ma}$, where the uncertainties are $95 \%$ confidence limits, and $n=74$.

TABLE 2. SUMMARY SHRIMP DATA FOR INDIVIDUAL ANALYTICAL SESSIONS ON EACH CRYSTAL OF GRENVILLE SKARN TITANITE

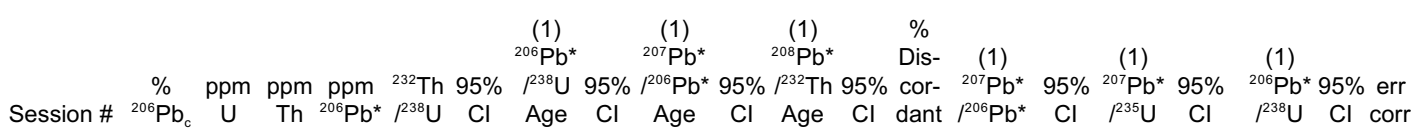

\section{OLT1}

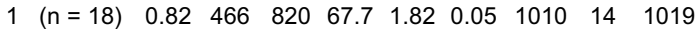

$\begin{array}{lllllllllll}2 & (\mathrm{n}=21) & 0.85 & 589 & 1062 & 87 & 2.02 & 0.01 & 1019 & 8 & 1006\end{array}$

$\begin{array}{lllllllllll}3 & (n=28) & 1.66 & 289 & 707 & 42 & 2.54 & 0.07 & 1017 & 5 & 1021\end{array}$

$\begin{array}{lllllllllll}4 & (\mathrm{n}=20) & 1.19 & 455 & 1171 & 67 & 2.56 & 0.08 & 1017 & 9 & 1021\end{array}$

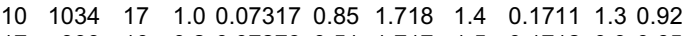
$\begin{array}{lllllllllll}17 & 999 & 10 & 0.2 & 0.07273 & 0.51 & 1.717 & 1.5 & 0.1712 & 0.9 & 0.65\end{array}$ $\begin{array}{lllllllllll}16 & 1011 & 5 & 0.7 & 0.07326 & 0.78 & 1.720 & 1.0 & 0.1708 & 0.6 & 0.59\end{array}$ $\begin{array}{lllllllllll}16 & 1045 & 17 & 0.5 & 0.07325 & 0.79 & 1.725 & 1.2 & 0.1708 & 1.0 & 0.67\end{array}$

OLT2

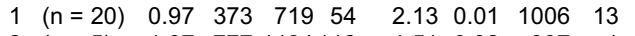

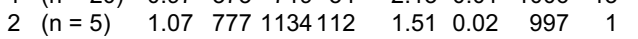

$\begin{array}{llllllllll}3 & (n=29) & 0.97 & 188 & 378 & 26.9 & 2.07 & 0.01 & 993 & 4\end{array}$

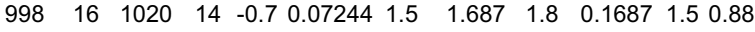

$\begin{array}{llllllllllll}989 & 30 & 963 & 21 & -1.0 & 0.07210 & 1.5 & 1.663 & 2.0 & 0.1673 & 0.1 & 0.42\end{array}$

$\begin{array}{llllllllllll}1023 & 16 & 1000 & 5 & 3.0 & 0.07334 & 0.8 & 1.682 & 0.9 & 0.1664 & 0.5 & 0.74\end{array}$

TCB

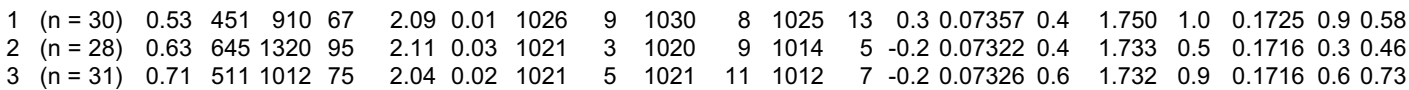



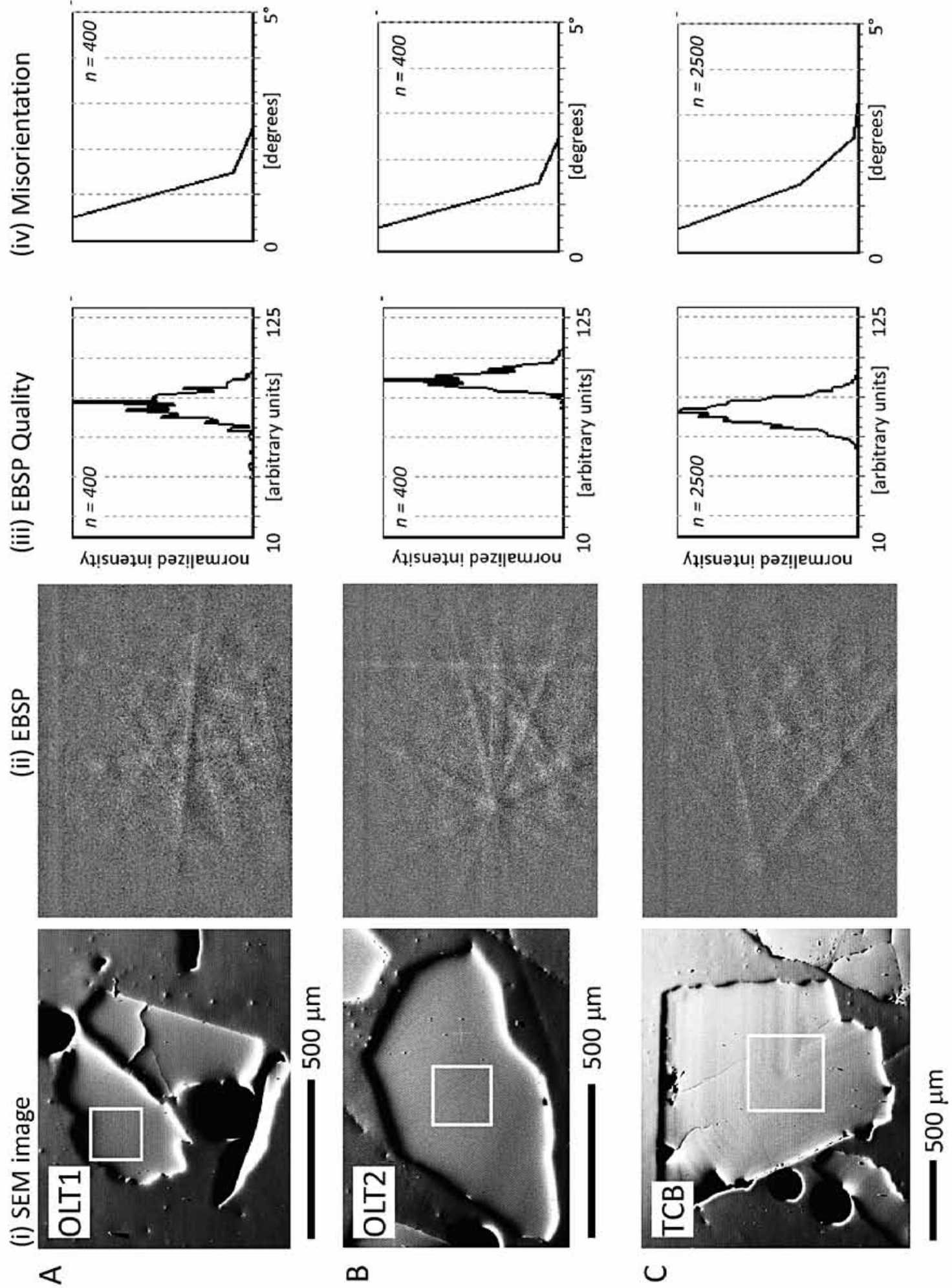
TABLE 3. TIMS DATA FOR CRYSTALS OF GRENVILLE SKARN TITANITE

\begin{tabular}{|c|c|c|c|c|c|c|c|c|c|c|c|c|c|c|c|c|}
\hline $\begin{array}{l}\text { Weight U } \\
(\mathrm{mg})(\mathrm{ppm})\end{array}$ & $\begin{array}{l}\text { Th } \\
\text { U }\end{array}$ & $\begin{array}{l}\mathrm{Pb}_{\text {tot }} \\
(\mathrm{pg})\end{array}$ & $\begin{array}{c}\mathrm{Pb}_{\text {com }} \\
(\mathrm{pg})\end{array}$ & $\begin{array}{l}{ }^{206} \mathrm{~Pb} \\
{ }^{204} \mathrm{~Pb} \\
\text { meas. }\end{array}$ & $\begin{array}{l}{ }^{207} \mathrm{~Pb} \\
{ }^{235} \mathrm{U}\end{array}$ & $2 \sigma$ & $\begin{array}{l}{ }^{206} \mathrm{~Pb} \\
{ }^{238} \mathrm{U}\end{array}$ & $2 \sigma$ & $\begin{array}{r}\text { error } \\
\text { corr. } \\
\text { A }\end{array}$ & $\begin{array}{c}{ }^{207} \mathrm{~Pb} \\
{ }^{235} \mathrm{U} \\
\text { ge }(\mathrm{Ma})\end{array}$ & $2 \sigma$ & $\begin{array}{c}{ }^{206} \mathrm{~Pb} \\
{ }^{238} \mathrm{U} \\
\text { Age (Ma) }\end{array}$ & $2 \sigma$ & $\begin{array}{c}{ }^{207} \mathrm{~Pb} \\
{ }^{206} \mathrm{~Pb} \\
\text { Age (Ma) }\end{array}$ & $2 \sigma$ & $\begin{array}{c}\% \\
\text { Disc. }\end{array}$ \\
\hline
\end{tabular}

\section{OLT-1}

$\begin{array}{rrrrrrrrrrrrrrrrrrr}1 & 0.095 & 350 & 1.81 & 8049 & 152.1 & 2279.4 & 1.7089 & 0.0059 & 0.16987 & 0.00041 & 0.798 & 1011.9 & 2.2 & 1011.4 & 2.3 & 1013.0 & 4.3 & 0.2 \\ 2 & 0.075 & 334 & 1.92 & 6240 & 147.6 & 1780.3 & 1.7224 & 0.0060 & 0.17074 & 0.00034 & 0.687 & 1016.9 & 2.2 & 1016.2 & 1.9 & 1018.6 & 5.2 & 0.3 \\ 3 & 0.084 & 338 & 1.93 & 7232 & 259.0 & 1163.8 & 1.7355 & 0.0179 & 0.17186 & 0.00162 & 0.926 & 1021.8 & 6.6 & 1022.3 & 8.9 & 1020.6 & 7.9 & -0.2 \\ 4 & 0.069 & 343 & 1.92 & 5868 & 117.9 & 2110.5 & 1.7236 & 0.0094 & 0.17072 & 0.00061 & 0.658 & 1017.4 & 3.5 & 1016.1 & 3.4 & 1020.2 & 8.3 & 0.4 \\ 5 & 0.097 & 328 & 1.91 & 7870 & 178.6 & 1865.2 & 1.7162 & 0.0087 & 0.17030 & 0.00036 & 0.474 & 1014.6 & 3.3 & 1013.8 & 2.0 & 1016.4 & 9.1 & 0.3 \\ 6 & 0.103 & 318 & 1.91 & 8117 & 182.3 & 1883.8 & 1.7219 & 0.0101 & 0.17060 & 0.00062 & 0.651 & 1016.7 & 3.8 & 1015.4 & 3.4 & 1019.6 & 9.0 & 0.5 \\ 7 & 0.056 & 286 & 1.52 & 3606 & 88.5 & 1862.9 & 1.6728 & 0.0088 & 0.16672 & 0.00045 & 0.563 & 998.3 & 3.3 & 994.0 & 2.5 & 1007.6 & 8.8 & 1.5\end{array}$

OLT-2

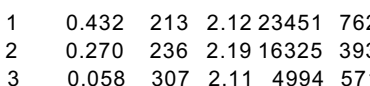

$\begin{array}{lllll}0.058 & 307 & 2.11 & 4994 & 571\end{array}$

\author{
1241 \\ 1665 \\ 337 \\ $\begin{array}{lllll}1.6630 & 0.0123 & 0.16672 & 0.00105 & 0.866 \\ 1.6719 & 0.0065 & 0.16714 & 0.00040 & 0.699\end{array}$ \\ $\begin{array}{llllll}1.6709 & 0.0450 & 0.16855 & 0.00070 & 0.131\end{array}$
}

$\begin{array}{lllllll}994.5 & 4.7 & 994.0 & 5.8 & 995.6 & 7.6 & 0.2\end{array}$ $\begin{array}{lllllll}997.9 & 2.5 & 996.3 & 2.2 & 1001.5 & 5.7 & 0.6\end{array}$

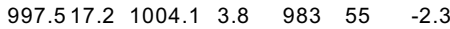

\section{TCB}

$\begin{array}{rrrrrr}1 & 0.068 & 411 & 2.05 & 7071 & 127 \\ 2 & 0.138 & 338 & 2.10 & 11925 & 222 \\ 3 & 0.080 & 262 & 2.04 & 5308 & 108 \\ 4 & 0.194 & 344 & 2.07 & 17221 & 458\end{array}$

\section{2}

2192

2039

1534

\begin{abstract}
$\begin{array}{llllllllllll}1.7223 & 0.0088 & 0.17052 & 0.00081 & 0.915 & 1016.9 & 3.3 & 1015.0 & 4.4 & 1021.0 & 4.2 & 0.6\end{array}$ $\begin{array}{llllllllllll}1.7227 & 0.0124 & 0.17062 & 0.00115 & 0.952 & 1017.0 & 4.6 & 1015.5 & 6.4 & 1020.2 & 4.5 & 0.5\end{array}$ $\begin{array}{lllllllllllll}1.7254 & 0.0067 & 0.17084 & 0.00049 & 0.811 & 1018.0 & 2.5 & 1016.7 & 2.7 & 1020.8 & 4.6 & 0.4\end{array}$

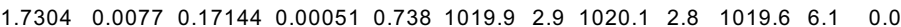

$\mathrm{Pb}_{\text {tot }}$ is total amount of $\mathrm{Pb}$ excluding blank. $\mathrm{Pb}_{\text {com }}$ is the total amount of common $\mathrm{Pb}$ (corrected using Stacey \& Kramers (1975) $\mathrm{Pb}$ evolution model). 206/204 corrected for fractionation and common $\mathrm{Pb}$ in the spike; $\mathrm{Pb} / \mathrm{U}$ ratios also corrected for blank. Correction for ${ }^{230} \mathrm{Th}$ disequilibrium in ${ }^{206} \mathrm{~Pb} /{ }^{238} \mathrm{U}$ and ${ }^{207} \mathrm{~Pb} /{ }^{206} \mathrm{~Pb}$ assuming $\mathrm{Th} / \mathrm{U}$ of 4.2 in the magma.

$\mathrm{Th} / \mathrm{U}$ is calculated from radiogenic ${ }^{208} \mathrm{~Pb} /{ }^{206} \mathrm{~Pb}$ ratio and ${ }^{207} \mathrm{~Pb} /{ }^{206} \mathrm{~Pb}$ age assuming concordance. Disc is percent discordance for the given ${ }^{207} \mathrm{~Pb} /{ }^{206} \mathrm{~Pb}$ age. Error Corr is correlation coefficients of $\mathrm{X}-\mathrm{Y}$ errors on the concordia plot.

To improve our confidence in the homogeneity of TCB, the second dataset of 28 analyses for TCB had longer count-intervals. The 28 analyses of this dataset exhibit very little scatter, and give a Tukey's bi-weighted mean ${ }^{206} \mathrm{~Pb} * 238 \mathrm{U}$ age of $1020.2 \pm 2.9 \mathrm{Ma}$ and a concordia age of $1020.3 \pm 1.2 \mathrm{Ma}$, MSWD $=0.17$, with a probability of concordance of 0.68 . The TCB data are plotted in Figure 5, with the excluded analyses from the first

FIG. 4. Electron-backscatter diffraction analysis of (A) OLT1, (B) OLT2, and (C) TCB. (i) SEM images of the grains, (ii) example EBSP acquired during EBSD mapping from within the white boxes in (i). (iii) Histograms of EBSP quality (band contrast), acquired from areas indicated by white boxes in (i). The well-defined diffraction bands and high band-contrast values indicate that the crystallographic structure is intact and has not been severely altered by radiation damage. (iv) Variation in crystallographic orientation from mean orientation of areas indicated by white boxes in (i). Each chart shows that crystallographic orientation varies less than $3^{\circ}$ across the grain. The results shown here are typical of the results for the other GST. dataset shown as dashed ellipses, along with the calculated concordia ellipse for the combined dataset.

\section{TIMS results}

The TIMS results (Table 3, Fig. 5) show that the three crystals (OLT1, OLT2 and TCB) each give concordant $\mathrm{U}-\mathrm{Pb}$ ages. Data for OLT1 and OLT2 show a slight scatter (i.e., in excess of that expected based on the uncertainty of individual analyses), and for OLT1, one of the seven analyses (Table 3) exhibits $\mathrm{Pb}$ loss. This dataset also has much lower $\mathrm{U}$ and $\mathrm{Th} / \mathrm{U}$ than other OLT1 datasets. Titanite crystals OLT1 and OLT2 have respective concordia ages of $1014.8 \pm 2.0$ $\mathrm{Ma}(2 \sigma, n=6, \mathrm{MSWD}=1.8)$ and $998.0 \pm 4.5 \mathrm{Ma}(2 \sigma$, $n=3$, MSWD $=3.3$ ). Four analyses of TCB are tightly clustered and give a concordia age of $1018.1 \pm 1.7 \mathrm{Ma}$ $(2 \sigma, \operatorname{MSWD}=0.92)$.

\section{DISCUSSION}

In SHRIMP geochronology applied to monazite and xenotime, matrix effects are a major concern, as changes in $\mathrm{Pb}^{+}, \mathrm{Th}^{+}, \mathrm{U}^{+}, \mathrm{ThO}^{+}, \mathrm{UO}^{+}, \mathrm{ThO}_{2}{ }^{+}$and $\mathrm{UO}_{2}{ }^{+}$ 

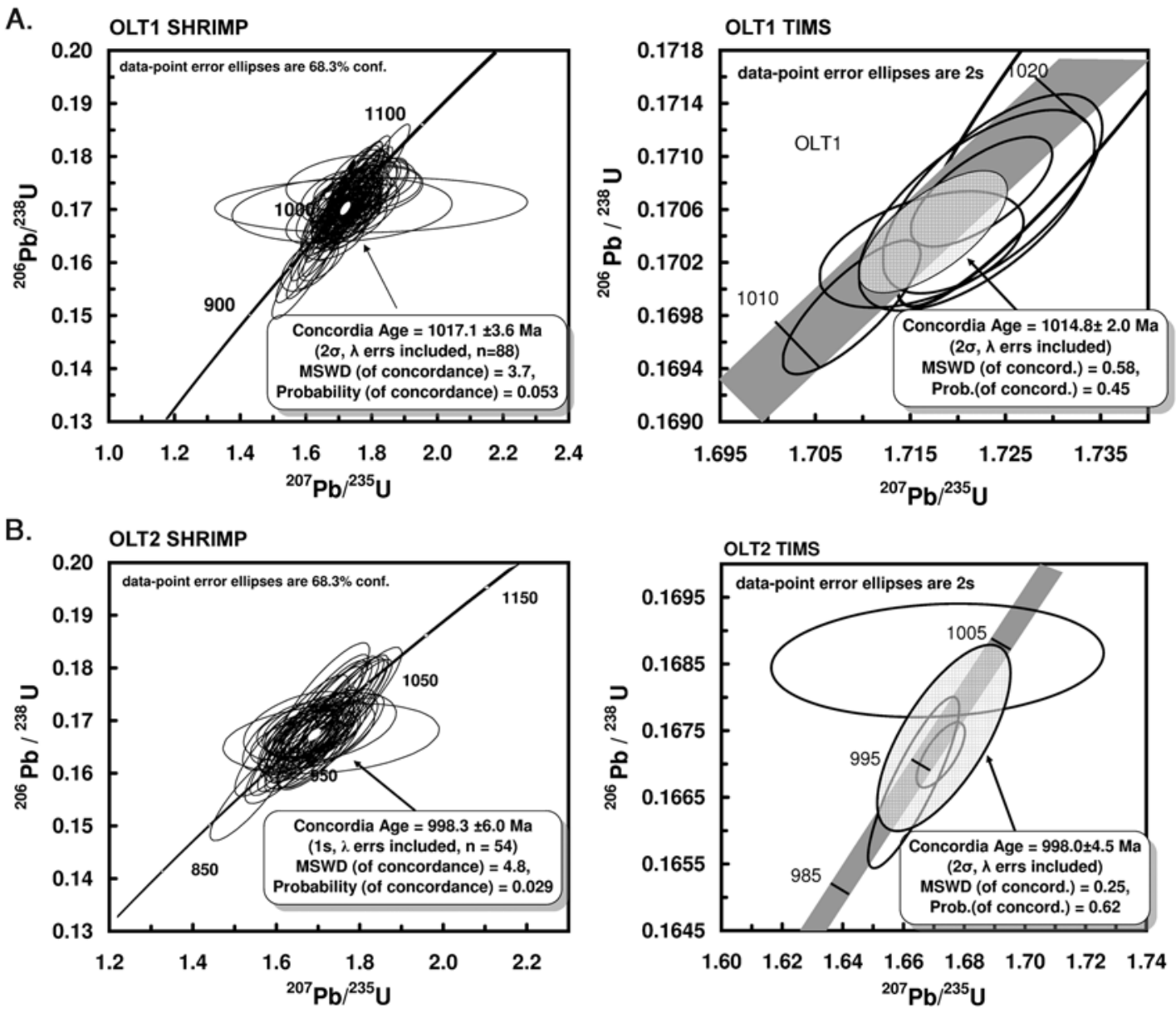

C.
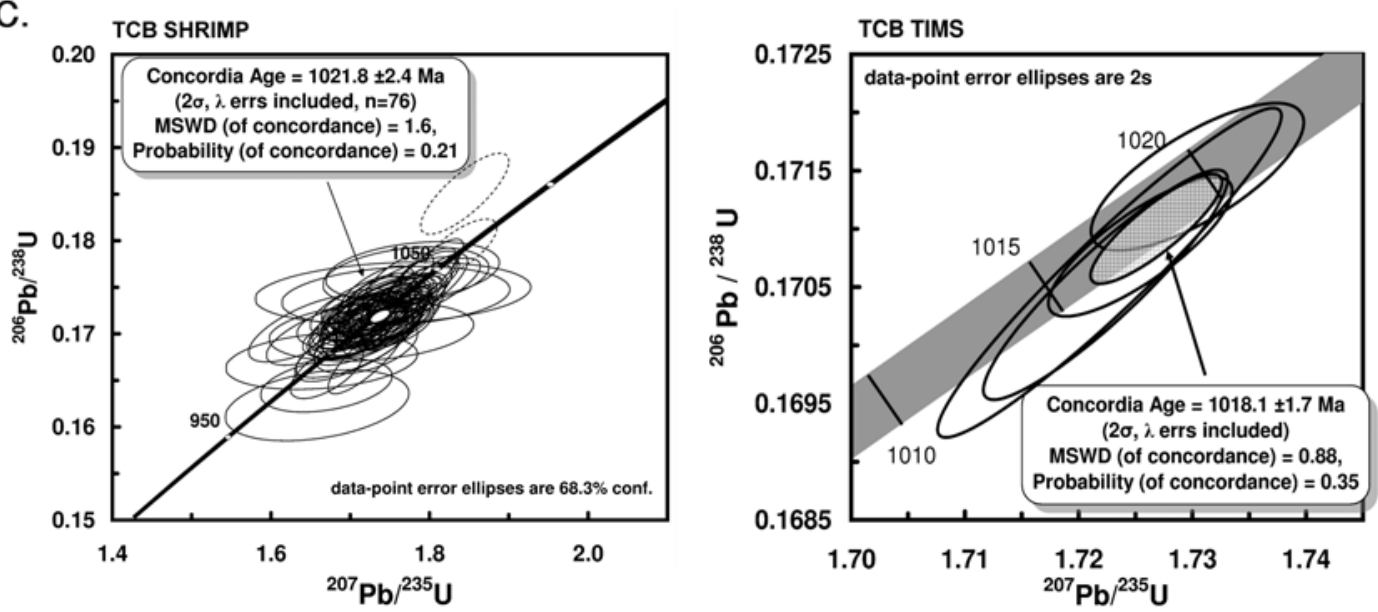

FIG. 5. Results of SHRIMP and TIMS U-Pb analyses of the GST plotted on Wetherill concordia diagrams. There are 88 SHRIMP analyses of OLT1, 54 of OLT2, and 76 of TCB. Open ellipses show the $1 \sigma$ uncertainties for the individual analyses for SHRIMP data, and $2 \sigma$ uncertainties for the individual TIMS analyses. Filled ellipses are calculated concordia ages from the datasets. Two SHRIMP analyses of TCB, shown as dashed error ellipses, are not included in the calculation of 
sputtering are produced by variations in the composition of the monazite and xenotime being analyzed. In some instances, the measured ratios of daughter to parent species, and hence calibrated ages, are $30-40 \%$ off from the TIMS value (Fletcher et al. 2010). We have not identified matrix effects within our datasets at our current level of precision. Even though the GST samples have highly variable major- and trace-element compositions, which are significantly different from the composition of the Khan titanite, our principal RM, our SHRIMP results are identical to the TIMS results. Any small difference between individual SHRIMP datasets and the TIMS results can easily be accounted for by assuming there is a small amount of Pb-loss in a few SHRIMP analyses, or that there is an odd poor analysis resulting from charging of the sample surface. Of course, there could be opposing matrix-effects that cancel out if there is a fortuitous balance of positive and negative effects associated with different elements. However, the GST samples do exhibit a range of compositions, with percentage-level variation for a large group of major elements, $\mathrm{Ti}, \mathrm{Fe}, \mathrm{Al}$, and $\mathrm{F}$, and tenths of a percent variation for a number of minor elements including $\mathrm{Nb}$, Th and $\mathrm{U}$. Because it is likely that a major matrix-effect would be identifiable in our datasets, we conclude that matrix effects are unimportant in titanite SHRIMP analysis for the specific samples of titanite that we have analyzed.

For SHRIMP U-Pb analyses, the individual spot uncertainties for calibrated ${ }^{206} \mathrm{~Pb} /{ }^{238} \mathrm{U}$ values are typically about $\pm 2 \%$ at $95 \%$ confidence (Stern \& Amelin 2003, Black et al. 2004, Fletcher et al. 2010, Stern et al. 2009). Our data consistently achieve this level of reproducibility for the standards. Individual analytical uncertainties for titanite are highly dependent on the amount of common $\mathrm{Pb}$ in the analysis, counting intervals and the $\mathrm{U}$ content.

A comprehensive study of instrumental massfractionation (IMF) of $\mathrm{Pb}$ isotopes during SHRIMP analysis of OG1, a $3.4 \mathrm{Ga}$ RM zircon, has shown that $\delta^{7-6} \mathrm{~Pb}$, the mean IMF value for ${ }^{207} \mathrm{~Pb}^{*} /{ }^{206} \mathrm{~Pb}^{*}$, is dispersed well beyond uncertainties, if the results of

the SHRIMP concordia age for TCB. One TIMS analysis of OLT1 (Table 3, anal. 7) that has lost $\mathrm{U}$, Th, and $\mathrm{Pb}$ plots outside the OLT1 diagram, with a ${ }^{206} \mathrm{~Pb}^{*} / 238 \mathrm{U}$ age of $998 \mathrm{Ma}$. It is not included in the calculation of the TIMS concordia age for OLT1. The calculated concordia uncertainty ellipse for each SHRIMP dataset is shown as a white ellipse. The different scales of the TIMS and SHRIMP diagrams mean that the concordia curve, which incorporates the uncertainties in the decay constants, appears as a band in the TIMS diagrams and as a thick line in the SHRIMP diagrams. individual analytical sessions are compared, with an observed total range of 6\%o (Stern et al. 2009). In over 26 zircon analytical sessions on three SHRIMP installations, Stern et al. (2009) measured an enhancement in ${ }^{207} \mathrm{~Pb}^{*}$ relative to ${ }^{206} \mathrm{~Pb} *$ of $\sim 0.7 \%$ o. Our ${ }^{207} \mathrm{~Pb}^{*} / 206 \mathrm{~Pb}^{*}$ data are not as precise owing to the lower abundance of ${ }^{207} \mathrm{~Pb}^{*}$ in the GST, and much larger common $\mathrm{Pb}$ corrections, owing to higher ${ }^{204} \mathrm{~Pb}$; however, there is little evidence for consistent variation of the mean ${ }^{207} \mathrm{~Pb}^{*} /{ }^{206} \mathrm{~Pb}^{*}$ in our titanite data. Figure 6 shows the weighted mean ${ }^{207} \mathrm{~Pb} * / 206 \mathrm{~Pb}^{*}$ age from individual SHRIMP sessions and the TIMS weighted mean ${ }^{207} \mathrm{~Pb}^{*} / 206 \mathrm{~Pb}^{*}$ age for each of the GST samples. For eight of the nine sessions, the SHRIMP and TIMS ages overlap, and there is no apparent IMF. In the third SHRIMP session for OLT2, the ${ }^{207} \mathrm{~Pb} * / 206 \mathrm{~Pb}^{*}$ age is $2.4 \%$ higher than the TIMS value. The data for this session could potentially be affected by incorrect placement of the ${ }^{204} \mathrm{~Pb}$ peak, producing slight undercounting of ${ }^{204} \mathrm{~Pb}$, or the presence of a small $\mathrm{Pb}$ hydride on ${ }^{207} \mathrm{~Pb}$, both of which would produce ${ }^{207} \mathrm{~Pb}^{* / 206} \mathrm{~Pb}^{*}$ values that are too high (Compston et al. 1984). Another possibility is that there is a difference between the true common $\mathrm{Pb}$ composition and the Stacey \& Kramers (1975) composition used in the data reduction. We have not been able to identify the cause of the higher than expected ${ }^{207} \mathrm{~Pb}^{*} / 206 \mathrm{~Pb}^{*}$ value in this session. We have not identified a titanite sample that can be used as an IMF monitor, as samples of Archean titanite, which would have sufficient ${ }^{207} \mathrm{~Pb}^{*}$, have on average $7 \%$ common $\mathrm{Pb}$ (Heaman \& Parrish 1991). The GST samples do not have sufficient ${ }^{207} \mathrm{~Pb}$ to be useful as IMF monitors. However, we would recommend the use of an IMF monitor, to confirm any instrumental problems producing a measurable IMF in titanite datasets.

The GST samples all contain minor amounts of common $\mathrm{Pb}$. However, titanite with lower common $\mathrm{Pb}$ and similar $\mathrm{U}$ contents is uncommon (Heaman \& Parrish 1991). Our results for the GST are internally consistent. We have found no relationship between age and composition, or for any age difference between the interior and outer edges of the crystals, suggesting that the titanite crystals grew over a relatively short time-interval.

There are five SHRIMP analyses of OLT1, one of OLT2, and two of TCB analyses in Figure 5 that plot at slightly younger ${ }^{206} \mathrm{~Pb} /{ }^{238} \mathrm{U}$ and ${ }^{207} \mathrm{~Pb} /{ }^{235} \mathrm{U}$ ages, consistent with minor $\mathrm{Pb}$ loss from some chips of the GST material. The effect of removing these datasets is small, making at most a 2.3 per mil difference in the mean age of the GST. The occurrence of minor $\mathrm{Pb}$ loss from OLT1 is confirmed by the TIMS data, with one analysis being clearly younger, with a ${ }^{206} \mathrm{~Pb} /{ }^{238} \mathrm{U}$ age of $998 \pm 2.5 \mathrm{Ma}$. This analysis has lower $\mathrm{U}, \mathrm{Pb}$, and $\mathrm{Th} / \mathrm{U}$, suggesting loss of $\mathrm{U}$, Th as well as $\mathrm{Pb}$. We do not consider this a result of a younger period of growth, as the small number of SHRIMP analyses that have younger ${ }^{206} \mathrm{~Pb} /{ }^{238} \mathrm{U}$ ages do not have younger 
${ }^{207} \mathrm{~Pb} /{ }^{206} \mathrm{~Pb}$ ages, a feature expected if they were formed during a younger period of growth. If the five analyses of OLT1 with younger ${ }^{206} \mathrm{~Pb} /{ }^{238} \mathrm{U}$ ages are removed, the concordia age becomes $1019.1 \pm 3.5 \mathrm{Ma}$ ( $2 \sigma$ uncertainty), MSWD for concordance is 1.7 , with a probability of concordance of 0.19 . The MSWD for concordance and equivalence is 0.64 , with a probability of 1.00. The new calculated age is further from the mean TIMS age than the age calculated with all SHRIMP analyses, so this removal may not be justified if the SHRIMP data are to be compared with the TIMS data.

A Lu-Hf age of $1031 \pm 6$ Ma for apatite OL-B8499 from one of the Otter Lake skarns has been interpreted as the age of the peak of the Ottawan orogeny metamorphism (Barfod et al. 2005), which would correspond to 650 to $700^{\circ} \mathrm{C}$ under fluid-rich conditions (Kretz 1990, Kretz et al. 1999). Our Otter Lake titanite ages are younger, and consistent with post-peak formation. Given their large size and homogeneous isotopic composition, it seems unlikely that the GST crystals recorded complete resetting 10-30 Ma after formation at the metamorphic peak. The calculated minimum closure-temperature for volume diffusion of $\mathrm{Pb}$ for $\mathrm{a}$ crystal of titanite with an effective diffusion radius of $1 \mathrm{~cm}$ is $>750^{\circ} \mathrm{C}$ (Cherniak 1993). Fast diffusion pathways may enhance diffusion and lower the temperatures needed for complete loss of radiogenic $\mathrm{Pb}$ in a system where the enclosing medium is $\mathrm{Pb}$ free. However, the relatively high partition-coefficient for $\mathrm{Pb}$ in titanite, with a value of approx. 1.0 (Prowatke \& Klemme 2005), and a Pb-bearing environment, such as a calcareous skarn, means that the total $\mathrm{Pb}$ loss required for complete geochronological resetting of $\mathrm{U}-\mathrm{Pb}$ ages is unlikely. We would rather ascribe the internally consistent but different $\mathrm{U}-\mathrm{Th}-\mathrm{Pb}$ ages of OLT1 and OLT2 to multiple episodes of titanite growth at Otter Lake, rather than to isotopic resetting.

\section{CONCLUSIONS}

Our data show that titanite crystals in Grenville skarns have potential as micro-analytical reference materials for $\mathrm{U}-\mathrm{Th}-\mathrm{Pb}$ analysis. The three large crystals of titanite that we characterized exhibit some heterogeneity in major- and trace-element composition, with relatively high levels of $\mathrm{Fe}, \mathrm{Al}$, and $\mathrm{F}$, and moderate amounts of radiation damage, but are large enough that high-quality isotopically homogeneous material can be hand-picked from crushed material. The titanite crystals have ages close to $1 \mathrm{Ga}, \mathrm{U}$ and Th contents that have produced high ${ }^{206} \mathrm{~Pb} /{ }^{204} \mathrm{~Pb}(500-2500)$ and high ${ }^{208} \mathrm{~Pb} /{ }^{204} \mathrm{~Pb}(200-1200)$, reducing the magnitude of the common $\mathrm{Pb}$ correction required for micro-analytical techniques. SHRIMP analysis of inclusion-free, unaltered regions of the crystals produces datasets with good $\mathrm{U}-\mathrm{Th}-\mathrm{Pb}$ isotopic homogeneity. Sample TCB is concordant, and isotopically homogeneous in TIMS analysis. Samples OLT1 and OLT2 are slightly heterogeneous in the U-Pb decay system at the scales of the TIMS analytical volume. However, this level of heterogeneity

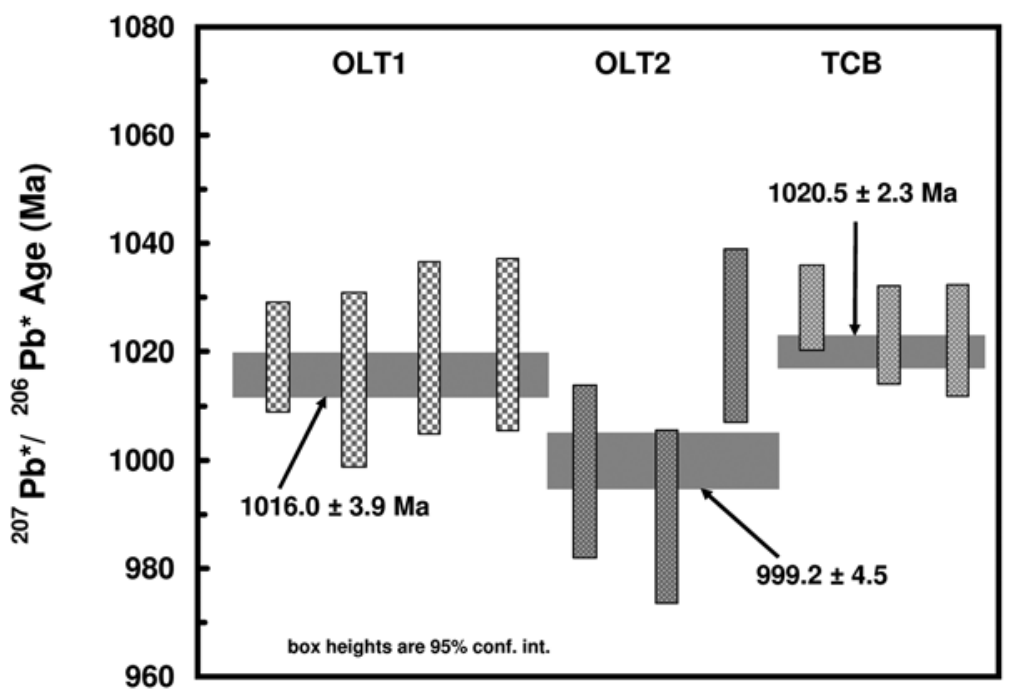

FIG. 6. Intrumental mass-fraction (IMF) of $\mathrm{Pb}$ isotopes or the SHRIMP analytical sessions. Vertical bars are the $95 \%$ confidence intervals for the weighted mean ${ }^{207} \mathrm{~Pb}^{*}{ }^{206} \mathrm{~Pb}^{*}$ age for the individual GST SHRIMP analytical sessions. The labeled horizontal grey bands are the $95 \%$ confidence limit of the weighted mean TIMS ${ }^{207} \mathrm{~Pb}^{*} /{ }^{206} \mathrm{~Pb}^{*}$ age for each GST. 
is smaller than that identified in any other titanite RM to which we have access. We conclude that the GST crystals are good micro-analytical RM that need further characterization. Small amounts $(\sim 100 \mathrm{mg})$ of OLT1 are available upon request from the senior author.

\section{ACKNOWLEDGEMENTS}

Mr. Adin Sehic of the JdeL SHRIMP Facility, and Dr. Janet Muhling of the CMCA, at UWA, assisted with WDS analysis at UWA. Our thanks go to Mr. Hao Gao for electronic and mechanical maintenance of the SHRIMP instruments. We are grateful to J. Aleinikoff and J. Wooden for very helpful reviews, and F. Mazdab for insightful comments. NCRIS, through the AUSCOPE program, provided technical support for this project. Nick Timms acknowledges funding from ARC Discovery Project DP0664078. Lutz Nasdala acknowledges partial funding for this research by the European Commission (contract MEXC-CT-2005-024878) and the Austrian Science Fund (FWF, grant P20028-N10). Sandra Kamo's research is supported by the Jack Satterly Laboratory, University of Toronto.

\section{REFERENCES}

Aleinikoff, J.N., Wintsch, R.P., Fanning, C.M. \& Dorais, M.J. (2002): U-Pb geochronology of zircon and polygenetic titanite from the Glastonbury Complex, Connecticut, USA: an integrated SEM, EMPA, TIMS, and SHRIMP study. Chem. Geol. 188, 125-147.

AleiniKoff, J.N., Wintsch, R.P., Tollo, R.P., UnRUh, D.M., FANNING, C.M. \& ScHMITZ, M.D. (2007): Ages and origins of rocks of the Killingworth dome, south-central Connecticut: implications for the tectonic evolution of southern New England. Am. J. Sci. 307, 63-118.

AmELIN, Y. (2009): Sm-Nd and U-Pb systematics of single titanite grains. Chem. Geol. 261, 53-61.

BAKKer, R.J. \& Elburg, M.A. (2006): A magmatic-hydrothermal transition in Arkaroola (northern Flinders Ranges, South Australia): from diopside-titanite pegmatites to hematite-quartz growth. Contrib. Mineral. Petrol. 152, 541-569.

Barfod, G.H., Krogstad, E.J., Frei, R. \& Albarède, F. (2005): Lu-Hf and PbSL geochronology of apatites from Proterozoic terranes: a first look at Lu-Hf isotopic closure in metamorphic apatite. Geochim. Cosmochim. Acta 69, 1847-1859.

Bernau, R. \& Franz, G. (1987): Crystal chemistry and genesis of Nb-, $\mathrm{V}-$, and Al-rich metamorphic titanite from Egypt and Greece. Can. Mineral. 25, 695-705.

Bismayer, U., Paulmann, C., Groat, L. \& Zhang, M. (2010): Local phenomena in metamict titanite. Acta Phys. Pol. A 117, 74-77.
Black, L.P., Kamo, S.L., Allen, C.M., Davis, D.W., AleiniKoff, J.N., Valley, J.W., Mundil, R., Campbell, I.H., KoRsCH, R.J., Williams, I.S. \& Foudoulis, C. (2004): Improved ${ }^{206} \mathrm{~Pb} /{ }^{238} \mathrm{U}$ microprobe geochronology by the monitoring of a trace-element related matrix effect, SHRIMP, ID-TIMS, ELA-ICP-MS, and oxygen isotope documentation for a series of zircon standards. Chem. Geol. 205, 115-140.

Buick, I.S., Hermann, J., MaAs, R. \& Gibson, R.L. (2007): The timing of sub-solidus hydrothermal alteration in the Central Zone, Limpopo Belt (South Africa): constraints from titanite $\mathrm{U}-\mathrm{Pb}$ geochronology and REE partitioning. Lithos 98, 97-117.

Cherniak, D.J. (1993): Lead diffusion in titanite and preliminary results on the effects of radiation damage on $\mathrm{Pb}$ transport. Chem. Geol. 110, 177-194.

Compston, W., Williams, I.S. \& Meyer, C. (1984): U-Pb geochronology of zircons from lunar breccia 73217 using a sensitive high mass-resolution ion microprobe. J. Geophys. Res. B89, 525-534.

Corfu, F. (1996): Multistage zircon and titanite growth and inheritance in an Archean gneiss complex, Winnipeg River Subprovince, Ontario Earth Planet. Sci. Lett. 141, 175-186.

Corfu, F. \& Stone, D. (1998): The significance of titanite and apatite $\mathrm{U}-\mathrm{Pb}$ ages: constraints for the post-magmatic thermal-hydrothermal evolution of a batholithic complex, Berens River area, northwestern Superior Province, Canada. Geochim. Cosmochim. Acta 62, 2979-2995.

Fletcher, I.R., McNaughton, N.J., Davis, W.J. \& RasmusSEN, B. (2010): Matrix effects and calibration limitations in ion probe $\mathrm{U}-\mathrm{Pb}$ and $\mathrm{Th}-\mathrm{Pb}$ dating of monazite. Chem. Geol. 270, 31-44.

FrANZ, G. \& SPEAR, F.S. (1985): Aluminous titanite (sphene) from the eclogite zone, south-central Tauern Window, Austria. Chem. Geol. 50, 33-46.

Frei, R., Villa, I.M., NÄgler, T.F., Kramers, J.D., PryzbyLowicz, W.J., Proseky, V.M., Hofmann, B.A. \& Kamber, B.S. (1997): Single mineral dating by the $\mathrm{Pb}-\mathrm{Pb}$ stepleaching method: assessing the mechanisms. Geochim. Cosmochim. Acta 61, 393-414.

Frost, B.R., Chamberlain, K.R. \& SchumaCheR, J.C. (2001): Sphene (titanite): phase relations and role as a geochronometer. Chem. Geol. 172, 131-148.

Frost, C.D. \& FAnNing, C.M. (2006): Archean geochronological framework of the Bighorn Mountains, Wyoming, Can. J. Earth Sci. 43, 1399-1418.

Gaft, M., Reisfeld, R. \& PAnczer, G. (2005): Modern Luminescence Spectroscopy of Minerals and Materials. Springer, Berlin, Germany. 
Gerstenberger, H. \& HaAse, G. (1997): A highly effective emitter substance for mass spectrometric $\mathrm{Pb}$ isotope ratio determinations. Chem. Geol. 136, 309-312.

Getty, S.R. \& Gromet, L.P. (1992): Geochronological constraints on ductile deformation, crustal extension, and doming around a basement-cover boundary, New England Appalachians. Am. J. Sci. 292, 359-397.

Hayden, L.A., Watson, E.B. \& Wark, D.A. (2008): A thermobarometer for sphene (titanite). Contrib. Mineral. Petrol. 155, 529-540.

Heaman, L.M. (2009): The application of U-Pb geochronology to mafic, ultramafic and alkaline rocks: an evaluation of three mineral standards. Chem. Geol. 261, 43-52.

HEAMAN, L.M. \& PARRISH, R.R. (1991): U-Pb geochronology of accessory minerals. In Applications of Radiogenic Isotope Systems to Problems in Geology (L. Heaman \& J.N. Ludden, eds.). Mineral. Assoc. Can., Short Course 19, 59-102.

Hollabaugh, C.L. \& Rosenberg, P.E. (1983): Substitution of $\mathrm{Ti}$ for $\mathrm{Si}$ in titanite and new end-member cell dimensions for titanite. Am. Mineral. 68, 177-180.

Jaffey, A.H., Flynn, K.F., Glendenin, L.E., Bentley, W.C. \& EssLing, A.M. (1971): Precision measurement of halflives and specific activities of ${ }^{235} \mathrm{U}$ and ${ }^{238} \mathrm{U}$. Phys. Rev. C4, 1889-1906.

Kamo, S.L., Wasteneys, H., Gower, C.F. \& Krogh, T.E. (1996): U-Pb geochronology of Labradorian and later events in the Grenville Province, eastern Labrador. Precamb. Res. 80, 239-260.

Ketchum, J.W.F., Heaman, L.M., Krogh, T.E., Culshaw, N.G. \& JAMIESON, R.A. (1998): Timing and thermal influence of late orogenic extension in the lower crust: a U-Pb geochronological study from the southwest Grenville orogen, Canada. Precamb. Res. 89, 25-45.

KinNY, P.D. (1997): Users' Guide to U-Th-Pb Dating of Titanite, Perovskite, Monazite and Baddeleyite Using the W.A. SHRIMP. School of Physical Sciences, Curtin University, Bentley, Australia (Rep. SPS 693/1997/AP72).

KRETZ, R. (1990): Biotite and garnet compositional variation and mineral equilibria in Grenville gneisses of the Otter Lake area, Quebec. J. Metam. Geol. 8, 493-506.

Kretz, R. (1993): Petrology of veined gneisses of the Otter complex, southern Grenville Province. Can. J. Earth Sci. 31, 835-851.

KRETZ, R. (2009): Metasomatic transformations in two metamorphic complexes dominated by heterogeneous Ca-pyroxene - hornblende granite and syenite, Otter Lake area, Quebec, Canada. Can. Mineral. 47, 1137-1158.

Kretz, R., Campbell, J.L., Hoffman, E.L., Hartree, R. \& TeESDALE, W.J. (1999): Approaches to equilibrium in the distribution of trace elements among the principal miner- als in a high-grade metamorphic terrane. J. Metam. Geol. 17, 41-59.

KROGH, T.E. (1973): A low contamination method for hydrothermal decomposition of zircon and extraction of $\mathrm{U}$ and $\mathrm{Pb}$ for isotopic age determination. Geochim. Cosmochim. Acta 37, 485-494.

LuDwIG, K.R. (2003): Isoplot-3.00, a Geochronological Toolkit for Microsoft Excel. Berkeley Geochronology Center, University of California, Berkeley, California (Spec. Publ. 4).

Ludwig, K.R. (2009): Squid 2, a User's Manual. Berkeley Geochronology Center, University of California, Berkeley, California (Spec. Publ. 2).

MarkL, G. \& Piazolo, S. (1999): Stability of high-Al titanite from low-pressure calcsilicates in light of fluid and hostrock composition. Am. Mineral. 84, 37-47.

Marks, A.W., Coulson, I.M., Schilling, J., Jacob, D.E., SChMitT, A.K. \& MARKL, G. (2008): The effect of titanite and other HFSE-rich mineral (Ti-bearing andradite, zircon, eudialyte) fractionation on the geochemical evolution of silicate melts. Chem. Geol. 257, 153-172.

MAZDAB, F.K. (2009): Characterization of flux-grown traceelement-doped titanite using the high-mass-resolution ion microprobe (SHRIMP-RG). Can. Mineral. 47, 813-831.

Meyer, H.W., Zhang, Ming, Bismayer, U., Salje, E.K.H., Schmidt, C., Kek, S., Morgenroth, W. \& Bleser, T. (1996): Phase transformation of natural titanite: an infrared, Raman spectroscopic, optical birefringence and X-ray diffraction study. Phase Trans. 59, 39-60.

MezGer, K., Rawnsley, C.M., Bohlen, S.R. \& Hanson, G.N. (1991): U-Pb garnet, sphene, monazite, and rutile ages: implications for the duration of high-grade metamorphism and cooling histories, Adirondack Mts., New York. J. Geol. 99, 415-428.

Murakami, T., Chakoumakos, B.C., Ewing, R.C., Lumpkin, G.R. \& WEBER, W.J. (1991): Alpha-decay event damage in zircon. Am. Mineral. 76, 1510-1532.

Nasdala, L., Grötzschel, R., Probst, S. \& Bleinsteiner, B. (2010): Irradiation damage in monazite $\left(\mathrm{CePO}_{4}\right)$ : an example to establish the limits of Raman confocality and depth resolution. Can. Mineral. 48, 351-359.

Nasdala, L., Hofmeister, W., Norberg, N., Mattinson, J.M., Corfu, F., Dörr, W., Kamo, S.L., Kennedy, A.K., Kronz, A., Reiners, P.w., Frei, D., Kosler, J., Wan, Yusheng, Götze, J., HäGer, T., KRÖNer, A. \& VAlley, J.W. (2008): Zircon M257 - a homogeneous natural reference material for the ion microprobe $\mathrm{U}-\mathrm{Pb}$ analysis of zircon. Geostand. Geoanal. Res. 32, 247-265.

Nasdala, L., Irmer, G. \& Wolf, D. (1995): The degree of metamictization in zircons: a Raman spectroscopic study. Eur. J. Mineral. 7, 471-478. 
NAsDALA, L. \& Massonne, H.-J. (2000): Microdiamonds from the Saxonian Erzgebirge, Germany: in situ micro-Raman characterization. Eur. J. Mineral. 12, 495-498.

Nasdala, L., Reiners, P.W., Garver, J.I., Kennedy, A.K., Stern, R.A., BALAN, E. \& WirTh, R. (2004): Incomplete retention of radiation damage in zircon from Sri Lanka. Am. Mineral. 89, 219-231.

Nemchin, A., Timms, N., Pidgeon, R., Geisler, T., Reddy, S. \& MEYeR, C. (2009): Timing of crystallization of the lunar magma ocean constrained by the oldest zircon. Nat. Geosci. 2, 133-136.

ØDEgÅrd, M., SkÅr, Ø., Schiellerup, H. \& PeArson, N.J. (2007): Preparation of a synthetic titanite glass calibration material for in situ microanalysis by direct fusion in graphite electrodes: a preliminary characterisation by EPMA and LA-ICP-MS. Geostand. Geoanal. Res. 29, 197-209.

Panczer, G., Seydoux-Guillaume, A.-M., Montel, J.-M. \& Champagnon, B. (2003): Tracing irradiation-induced defect state of monazite by photoluminescence of rare earth element. Geophys. Res. Abstr. 5, 14148.

Panczer, G., Seydoux-Guillaume, A.-M., Ollier, N., MonTEL, J.-M. \& Champagnon, B. (2005): Photoluminescence as a tool to probe nuclear waste storage matrixes. Geophys. Res. Abstr., 7, 04851.

PARrish, R.R. \& Whitehouse, M.J. (1999): Constraints on the diffusivity of $\mathrm{Pb}$ in monazite, its closure temperature, and its U-Th-Pb systematics in metamorphic terrains, from a TIMS and SIMS study. J. Conf. Abstr. 4(1), 711.

Paterson, B.A. \& Stephens, W.E. (1992): Kineticallyinduced compositional zoning in titanites: implication for accessory-phase/melt partitioning of trace elements. Contrib. Mineral. Petrol. 109, 373-385.

Pidgeon, R.T., Bosch, D. \& Bruguier, O. (1996): Inherited zircon and titanite $\mathrm{U}-\mathrm{Pb}$ systems in an Archean syenite from southwestern Australia: implications for U-Pb stability of titanite. Earth Planet. Sci. Lett. 141, 187-198.

Prowatke, S. \& Klemme, S. (2005): Effect of melt composition on the partitioning of trace elements between titanite and silicate melt. Geochim. Cosmochim. Acta 69, 695-709.

Rasmussen, B., Fletcher, I.R. \& Muhling, J.R. (2008): Pb/ $\mathrm{Pb}$ geochronology, petrography and chemistry of $\mathrm{Zr}$-rich accessory minerals (zirconolite, tranquillityite and baddeleyite) in Mare basalt 10047. Geochim. Cosmochim. Acta 72, 5799-5818.

Reddy, S.M., Timms, N.E. \& EgLington, B.M. (2008): Electron backscatter diffraction analysis of zircon: a systematic assessment of match unit characteristics and pattern indexing optimization. Am. Mineral. 93, 187-197.

Reddy, S.M., Timms, N.E., Pantleon, W. \& Trimby, T. (2007): Quantitative characterization of plastic deformation of zircon and geological implications. Contrib. Mineral. Petrol. 153, 625-645.
Schoene, B., Crowley, J.L., Condon, D.J., Schmitz, M.D. \& Bowring, S.A. (2006): Reassessing the uranium decay constants for geochronology using ID-TIMS U-Pb data. Geochim. Cosmochim. Acta 70, 426-445.

SEIFERT, W. (2005): REE-, Zr-, and Th-rich titanite and associated accessory minerals from a kersantite in the Frankenwald, Germany. Mineral. Petrol. 84, 129-146.

Seydoux-Guillaume, A.-M., Wirth, R., Nasdala, L., GotTSCHALK, M., Montel, J.-M. \& HeInRICH, W. (2002): An XRD, TEM and Raman study of experimentally annealed natural monazite. Phys. Chem. Minerals 29, 240-253.

SHAw, D.M. (1958): Radioactive mineral occurrences of the province of Québec. Quebec Dep. Mines, Geol. Rep. 80.

Shaw, D.M., Moxham, R.L., Filby, R.H. \& Lapkowsky, W.W. (1963a): The petrology and geochemistry of some Grenville skarns. I. Geology and petrography. Can. Mineral. 7, 420-442.

Shaw, D.M., Moxham, R.L., Filby, R.H. \& Lapkowsky, W.W. (1963b): The petrology and geochemistry of some Grenville skarns. II. Geochemistry. Can. Mineral. 7, 578-616.

Smith, M.P., Storey, C.D., JefFeries, T.E. \& RyAn, C. (2009): In situ $\mathrm{U}-\mathrm{Pb}$ and trace element analysis of accessory minerals in the Kiruna district, Norrbotten, Sweden: new constraints on the timing and origin of mineralization. $J$. Petrol. 50, 2063-2094.

SPEAR, F.S. (1981): An experimental study of hornblende stability and compositional variability in amphibolite, $\mathrm{Am}$. J. Sci. 281, 697-734.

Stacey, J.S. \& Kramers, J.D. (1975): Approximation of terrestrial lead isotope evolution by a two-stage model. Earth Planet. Sci. Lett. 26, 207-221.

STERN, R.A. \& Amelin, Y. (2003): Assessment of errors in SIMS zircon $\mathrm{U}-\mathrm{Pb}$ geochronology using a natural zircon standard and NIST SRM 610 glass. Chem. Geol. 197, 111-142.

Stern, R.A., Bodorkos, S., Kamo, S.L., Hickman, A.H. \& Corfu, F. (2009): Measurement of SIMS instrumental mass fractionation of $\mathrm{Pb}$ isotopes during zircon dating. Geostand. Geoanal. Res. 33, 145-168.

Storey, C.D., JefFeries, T.E. \& SMith, M. (2006): Common lead-corrected laser ablation ICP-MS U-Pb systematics and geochronology of titanite. Chem. Geol. 227, 37-52.

Storkey, A., Hermann, J., Hand, M. \& Buick, I.S. (2005): Using in-situ trace element determinations to monitor partial-melting processes in metabasites. J. Petrol. 46, 1283-1308.

Timms, N.E., Kinny, P.D. \& RedDy, S.M. (2006): Enhanced diffusion of uranium and thorium linked to crystal plasticity in zircon. Geochem. Trans. 7, 10 [doi: 10.1186/14674866-7-10]. 
TROPPER, P. \& MANNING, C.E. (2008): The current status of titanite-rutile thermobarometry in ultrahigh-pressure metamorphic rocks: the influence of titanite activity models on phase equilibrium calculations. Chem. Geol. 254, 123-132.

Trzcienski, W.E., JR., Perrault, G. \& Herbert, P. (1974): A note on apatite from Huddersfield Township, Québec. Can. Mineral. 12, 289-291.

Verts, L.A., ChamberLain, K.R. \& Frost, C.D. (1996): U-Pb sphene dating of metamorphism: the importance of sphene growth in the contact aureole of the Red Mountain Pluton, Laramie Mountains, Wyoming. Contrib. Mineral. Petrol. 125, 186-199.

Weber, W.J., Ewing, R.C. \& WANG, Lu-Min (1994): The radiation-induced crystalline-to-amorphous transition in zircon. J. Mater. Res. 9, 688-698.

Williams, C.T. (1996): Analysis of rare earth minerals. In Rare Earth Minerals: Chemistry, Origin and Ore Deposits. (A.P. Jones, F. Wall \& C.T. Williams, eds.). Chapman and Hall, London, U.K. (327-348).
Wingate, M.T.D. \& ComPSTON, W. (2000): Crystal orientation effects during ion microprobe $\mathrm{U}-\mathrm{Pb}$ analysis of baddeleyite. Chem. Geol. 168, 75-97.

XIRouchaKIs, D. \& LinDSLEy, D.H. (1998): Equilibria among titanite, hedenbergite, fayalite, quartz, ilmenite, and magnetite. Experiments and internally consistent thermodynamic data for titanite. Am. Mineral. 83, 712-725.

Zhang, LiAn-Sheng \& SchäReR, U. (1996): Inherited Pb components in magmatic titanite and their consequence for the interpretation of $\mathrm{U}-\mathrm{Pb}$ ages. Earth Planet. Sci. Lett. 138, 1-4.

Zhang, Ming \& SALJE, E.K.H. (2003): Spectroscopic characterization of metamictization and recrystallization in zircon and titanite. Phase Trans. 76, 117-136.

Received June 22, 2010, revised manuscript accepted November 19, 2010. 


\section{Appendix 1. ShRIMP Technical Details}

The analytical conditions are as follows. A 2-3 $\mathrm{nA}, 10 \mathrm{keV}, \mathrm{O}_{2}^{-}$primary beam, which is focussed into an elliptical spot with a maximum length of 20-30 $\mu \mathrm{m}$, sputters $\mathrm{M}^{+}$secondary ions, which are accelerated to $10 \mathrm{kV}$, and refocused through an electrostatic analyzer (ESA) and magnet, to produce a secondary beam of the ions of interest, with a mass resolution of $>5000(\mathrm{M} /$ $\Delta M$ at $1 \%$ peak height) and a $\mathrm{Pb}^{+}$sensitivity of $16-20$ $\mathrm{cps} / \mathrm{ppm} / \mathrm{nA}$. This secondary signal is pulse-counted with a ETP® $\mathrm{AF} 150 \mathrm{H}$, discrete dynode, electron multiplier. The measured dead-time for the counting system is $25 \mathrm{~ns}$.

The primary beam is rastered over a $30 \times 20 \mu \mathrm{m}$ rectangle for 2.0 or 2.5 minutes prior to data collection, to reduce surface contributions by common $\mathrm{Pb}$. Analyses have six cycles through the data acquisition species. Peak centering occurs for all cycles, on all peaks, with the exception of the fixed dispersion peaks ${ }^{204} \mathrm{~Pb}^{+}$, and background, which are referenced to the preceding high count-peak, $\mathrm{CaTi}_{2} \mathrm{O}_{4}{ }^{+}$, and ${ }^{207} \mathrm{~Pb}^{+}$and ${ }^{208} \mathrm{~Pb}^{+}$, which are referenced to ${ }^{206} \mathrm{~Pb}^{+}$. The secondary ion species and data-collection sequence for titanite is based on the usual Perth SHRIMP procedure (Kinny 1997), but with the addition of ${ }^{232} \mathrm{Th}^{16} \mathrm{O}_{2}{ }^{+}$in some sessions. The oxide species ${ }^{238} \mathrm{U}^{16} \mathrm{O}^{+},{ }^{238} \mathrm{U}^{16} \mathrm{O}_{2}{ }^{+}$, ${ }^{232} \mathrm{Th}^{16} \mathrm{O}^{+}$and ${ }^{232} \mathrm{Th}^{16} \mathrm{O}_{2}{ }^{+}$, which have higher countrates than the elemental species ${ }^{238} \mathrm{U}^{+}$and ${ }^{232} \mathrm{Th}^{+}$, are used, because titanite can have low $\mathrm{U}$ and Th contents, and the use of ${ }^{238} \mathrm{U}^{+}$and ${ }^{232} \mathrm{Th}^{+}$can significantly reduce analytical precision. The $U$ abundance is calculated from the ratio of the UO peak and the reference peak $\mathrm{CaTi}_{2} \mathrm{O}_{4}{ }^{+}$using the $\mathrm{U}$ abundance of the standard. The measured count-rate of the $\mathrm{CaTi}_{2} \mathrm{O}_{4}{ }^{+}$peak is a function of the major-element chemistry of both the standard and unknowns and is highly sensitive to changes in conductivity and charging, and hence the uncertainties on the calculated $\mathrm{U}$ and Th contents are high, at $220 \%$. The $\mathrm{Th}$ abundance is calculated from the $\mathrm{U}$ abundance and the measured ratio ${ }^{232} \mathrm{Th}^{16} \mathrm{O}^{+} / 238 \mathrm{U}^{16} \mathrm{O}^{+}$.

The SHRIMP data are processed with SQUID2 (Ludwig 2009). The $\mathrm{U}$ contents are calibrated against the Khan titanite (584 ppm U, Heaman 2009), or the titanite TIMS data of Table 3. Calibration of the ratios of radiogenic daughter (denoted by $*$ ) to radioactive parent, such as ${ }^{206} \mathrm{~Pb}^{*} / 238 \mathrm{U}$, used either Khan titanite or one of the Grenville Skarn Titanite samples using a power law relationship, $\mathrm{A}=\mathrm{a} \times(\mathrm{B})^{\mathrm{m}}$, where $\mathrm{A}$ is a ratio of daughter to parent species, such as ${ }^{206} \mathrm{~Pb}^{*} / 238 \mathrm{U}$, ${ }^{206} \mathrm{~Pb} * /{ }^{238} \mathrm{U}^{16} \mathrm{O}$, or ${ }^{206} \mathrm{~Pb}{ }^{*} /{ }^{238} \mathrm{U}^{16} \mathrm{O}_{2}$, and $\mathrm{B}$ is typically a ratio of parent species, such as ${ }^{238} \mathrm{U}^{16} \mathrm{O} /{ }^{238} \mathrm{U}$, ${ }^{238} \mathrm{U}^{16} \mathrm{O}_{2} /{ }^{238} \mathrm{U}$, or ${ }^{238} \mathrm{U}^{16} \mathrm{O}_{2} /{ }^{238} \mathrm{U}^{16} \mathrm{O}$. The exponent in the equation, $\mathrm{m}$, is measured or assumed for each session (e.g., for the ${ }^{206} \mathrm{~Pb} * 238 \mathrm{U}^{16} \mathrm{O}$ to ${ }^{238} \mathrm{U}^{16} \mathrm{O}_{2} / 238 \mathrm{U}^{16} \mathrm{O}$ pair, which is our preferred scheme of calibration, the exponent is set at 0.83 if the measured exponent falls outside the range $0.80-0.86)$. SQUID2 calculates a 'calibration constant', a, for each analysis of the RM and an error-weighted mean and standard error for all of these analyses, plus the error on the calibration, and the external error from the standard dataset. For each analysis of an unknown, a value for $\mathrm{a}_{\text {unk }}$ and its uncertainty is calculated. The calculated age of the unknown is derived from ${ }^{206} \mathrm{~Pb}^{* / 238} \mathrm{U}_{\text {unk }}=\mathrm{a}_{\mathrm{unk}} / \mathrm{a}_{\mathrm{rm}}$ $\times{ }^{206} \mathrm{~Pb} * / 238 \mathrm{U}_{\mathrm{RM}}$ and the normal decay equations. Similar data-reduction procedures are available within SQUID2 for calculating ${ }^{208} \mathrm{~Pb}^{*} /{ }^{232} \mathrm{Th}$ ages. For the ${ }^{208} \mathrm{~Pb}-{ }^{232} \mathrm{Th}$ decay system, a calibration scheme with $\mathrm{A}={ }^{208} \mathrm{~Pb}^{*} / 232 \mathrm{Th}^{16} \mathrm{O}, \mathrm{B}={ }^{232} \mathrm{Th}^{16} \mathrm{O}_{2} /{ }^{232} \mathrm{Th}^{16} \mathrm{O}$ and an exponent $\mathrm{m}=0.905$ was used in data where two $\mathrm{Th}$ oxide species were measured. For the other datasets, the ${ }^{208} \mathrm{~Pb} * / 232 \mathrm{Th}$ ages were calculated indirectly by deriving Th contents from the measured ${ }^{232} \mathrm{Th}^{16} \mathrm{O} /{ }^{238} \mathrm{U}^{16} \mathrm{O}$ value. The Th content of Khan titanite is assumed to be 473 $\mathrm{ppm}$, and the ${ }^{208} \mathrm{~Pb} * / 232 \mathrm{Th}$ and ${ }^{206} \mathrm{~Pb}^{* / 238} \mathrm{U}$ decay systems are assumed to be concordant. This assumption has been proven incorrect for monazite RM (Fletcher $e t$ al. 2010), but TIMS Th concentrations have not been measured for the GST, so in the interim we have used this assumption. The ages and concordia plots use the ${ }^{238} \mathrm{U}$ decay constant of Jaffey et al. (1971), $1.55125 \times$ $10^{-10}$ and the revised ${ }^{235} \mathrm{U}$ decay constant of Schoene et al. (2006), $9.8569 \times 10^{-10}$. Both the internal and external uncertainty of the calibration constant have been included in the uncertainties of the ratios plotted in the figures, so that datasets collected on different mounts and different days are comparable. Uncertainties in calculated ages are listed as $\pm 2 \sigma$. Measured mean $\mathrm{Pb}$ isotope and parent/daughter ratios for each analysis are corrected for common $\mathrm{Pb}$. The ratio ${ }^{204} \mathrm{~Pb} * / 206 \mathrm{~Pb}$, and the estimated ${ }^{207} \mathrm{~Pb} * / 206 \mathrm{~Pb}$ age of the titanite, are used to correct for a common $\mathrm{Pb}$ composition calculated from the Stacey \& Kramers (1975) model of bulk-crustal Pb isotope composition. Robust means are less influenced by outliers and the assumption of a normal distribution than a simple uncertainty-weighted mean, and so we have chosen to use the Tukey's bi-weighted mean, as implemented in Isoplot 3 (Ludwig 2003) in discussing our data.

In addition to the GST titanite, covered in detail in this study, we made preliminary SHRIMP measurements on other titanite samples. Faceted gem titanite from Sri Lanka, Madagascar, and Russia was analyzed, but none had sufficient $\mathrm{U}$ or Th, and all had ${ }^{206} \mathrm{~Pb} /{ }^{204} \mathrm{~Pb}$ values $<100$. Similarly, GST titanite from the Smart mine of Lake Clear, Ontario, and the Lost mine at Eganville, Renfrew County, Ontario, were analyzed, but they have lower $U$ and Th than the Otter Lake and Campbell's Bay titanite, or high percentages of common $\mathrm{Pb}$, or isotopic heterogeneity, and therefore, have subsequently not been analyzed further. 
